\title{
Fractionation of REE, U, and Th in natural ore-forming hydrothermal systems: Thermodynamic modeling
}

\author{
A. Migdisov ${ }^{1 *}$, X. Guo ${ }^{2}$, H. Nisbet ${ }^{1}$, H. Xu${ }^{1}$, and A.E. Williams-Jones ${ }^{3}$ \\ 1. Earth and Environmental Sciences Division, Los Alamos National Laboratory, P.O. Box 1663, \\ M.S. J535, Los Alamos, NM 87545, USA \\ 2. Department of Chemistry and Alexandra Navrotsky Institute for Experimental \\ Thermodynamics, Washington State University, Pullman, WA 99164 \\ 3. Department of Earth and Planetary Sciences, McGill University, 3450 University Street, \\ Montreal, Canada, H3A 0E8
}

*artas@lanl.gov 


\begin{abstract}
:
This contribution presents a thermodynamic model revealing the mechanisms responsible for separation of Heavy and Light Rare Earth (HREE and LREE) phosphates in natural hydrothermal systems at temperatures of $250-350{ }^{\circ} \mathrm{C}$. Our calculations were performed for an isothermal column of rock containing $0.5 \mathrm{wt} \%$ of apatite (Ca phosphate), which served as an immobilizing agent for REE dissolved in the solution. REE were transported by $10 \mathrm{wt} \% \mathrm{NaCl}$ acidic solution. The model accounted for formation of REE phosphate solid solutions through a regular mixing model. It demonstrates that hydrothermal flushing can efficiently separate REE forming xenotime (HREE phosphate solid solutions) at the beginning of the column, and retransportation of monazite (LREE rich) to the end of the column. This separation is primarily due to the fact that at elevated temperatures stability LREE chloride complexes is significantly higher than that for HREE. The model also evaluates behavior of $U$ and Th, which accompany REE in vast majority of natural locations. It was found that $U$ strongly fractionates to xenotime, whereas Th fractionates to monazite. This phenomenon can be explained by the differences in crystalchemical characteristics between monazite and xenotime, and the mobility of $\mathrm{Th}$ in aqueous solutions at elevated temperatures.
\end{abstract}




\section{Introduction}

Development of new technologies, particularly those designed to address environmental

concerns, and those that are essential for renewable energy applications (such as wind turbines, solar panels, electric cars, and advanced batteries), has called for a great demand in Rare Earth Elements (REE) materials. The global production of REE, however, is largely restricted to a single country (China), and thus supplies of these elements are vulnerable to political and/or economic decisions that are beyond the control of global markets. As these elements are critical for the future economy, there has been considerable pressure to find new sources [1]. In the US alone, the annual REE consumption currently approaches 20,000 metric tons [2], and meeting such a scale of demand most likely requires sustainable domestic mining, which, in turn, suggests that either new natural sources of REE (new ore deposits) have to be found, or new technologies must be developed for more efficient extraction of these elements from existing sources. These goals (at least with regards to finding new sources) cannot be achieved without quantitative understanding of chemical mechanisms responsible for transport, fractionation, and concentration of REE in natural processes leading to the formation of natural REE deposits.

It is now almost universally agreed that hydrothermal fluids commonly mobilize the REE and concentrate to economic levels. Thus, besides the need for basic REE science, understanding the behavior of REE in hot aqueous solutions circulating in Earth's crust is required for developing tools to discover new economic REE supplies. Recently, we have summarized thermodynamic data currently available on the behavior of REE in hydrothermal systems and proposed a set of models, evaluating the main controls of the formation of monazites and xenotimes (REEphosphates, one of the main ore minerals supplying REE to industry) from natural solutions [3]. These models suggest the mobilization of REE in natural hydrothermal systems occurs primarily in acidic $(\mathrm{pH}<3)$ solutions rich in chloride- and sulfate, and depleted in fluoride- and phosphate, carrying REE in concentrations of up to several hundred ppm [4]. REE deposition is related to the encounter of these solutions with rocks containing apatite (Ca-phosphate). These models additionally investigated, to the first approximation, the conditions at which these processes can lead to the separation of Medium and Heavy REE (M/HREE) which are highly sought out in industry, from the less economically attractive Light REE (LREE).

It should be noted, however, that the models proposed in Migdisov et al. [3] are highly approximate. Mainly, the calculations reported did not account for the ability of REE phosphates to form multi-component solid solutions, where deposition and fractionation of the REE was modelled through corresponding pure end-member REE phosphates. This is a significant deficiency in the model: natural monazites and xenotimes always form solid solutions, which are more complex than end members [5]. Monazite solid solutions, which adopt a monoclinic structure (space group $P 2_{1} / n$, Figure 1-left), are predominated [6] by Ce, La, or Nd phosphates (Ce-, La-, and Nd-monazites, respectively) and can effectively incorporate all L/MREE (down to

$55 \mathrm{Gd})$ together with $\mathrm{U}$ and $\mathrm{Th}$ [7]. Xenotime solid solutions that possess a tetragonal structure (space group $I 4_{1} /$ amd, Figure 1-right), are typically predominated by $\mathrm{Y}$ phosphates and contain mostly HREE together with $U$ and Th [8]. The monazite structure is comprised of chains of alternating $\left[\mathrm{PO}_{4}\right]$ tetrahedra, and nine-fold coordinated REE and substituted U/Th (Fig. 1-left). The xenotime structure is of zircon $\left(\mathrm{ZrSiO}_{4}\right)$ type, consisting of eight-coordinated $\mathrm{REE} / \mathrm{U} / \mathrm{Th}$ site and $\left[\mathrm{PO}_{4}\right]$ (Fig. 1-right). The differences between the two structures result in their different preferences for REE/U/Th: monazite favors L/MREE and Th, while xenotime favors HREE and U. This behavior can simply be interpreted by the size effect of substituting ions, i.e., the larger 

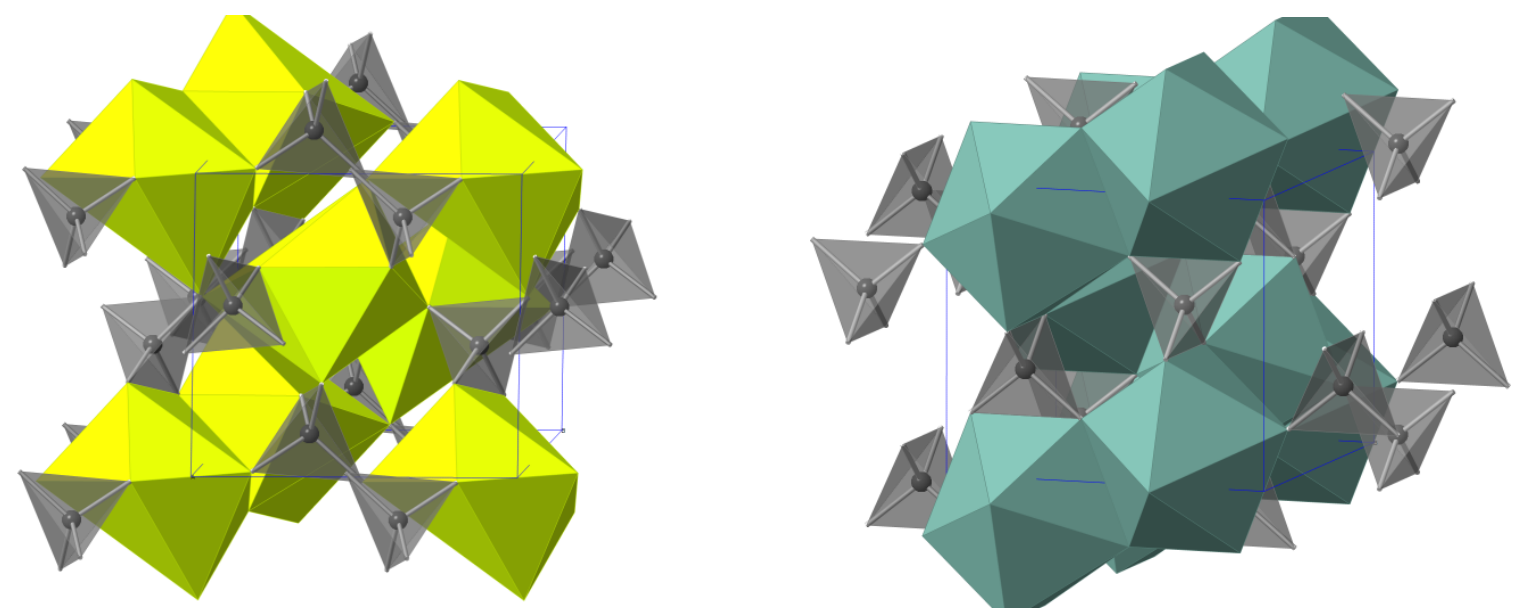

65

Figure 1. Crystal structures of monazite (left) and xenotime (right). The figures are drawn based on the structure data of $\mathrm{CePO}_{4}$ (left) and $\mathrm{YPO}_{4}$ (right) [6]. Grey tetrahedron represents $\left[\mathrm{PO}_{4}\right]$, yellow polyhedron represents $\left[\mathrm{CeO}_{9}\right]$ and blue polyhedron represents $\left[\mathrm{YO}_{8}\right]$. Blue lines denote the unit cell.

L/MREE and Th prefer the larger nine-fold coordinated site in monazite and the smaller HREE and $U$ prefer the smaller eight-fold coordinated site in xenotime [9]. However, due to the varying sizes among L/MREE/Th or HREE/U, their monazite or xenotime solid solutions expectedly exhibit non-ideal mixing behavior. As a result, reactivity of solid solution components can be significantly different from that of individual end-members, and can therefore modify or shift the main trends observed in end-member phases [3]. In addition, these models do not account for the occurrence of $U$ and $\mathrm{Th}$, whose presence (up to $20 \mathrm{wt} \%$ ) in monazite and xenotime poses significant problems for the REE mining industry as radioactive elements require special measures to be taken for their treatment and disposal, significantly increasing the REE recovery costs [10-12]. On the other hand, being the primary REE-bearing ore mineral, monazite with an elevated content of Th, is also the main Th ore mineral, and with respect to the Th mining industry, the role of Th in monazite shifts from a highly unwelcome contaminant to a main mining commodity. Hence, development of thermodynamic models that predict the formation of both U/Th-enriched and U/Th-depleted monazite/xenotime is crucial for the discovery of new, economically feasible, resources of REE while fulfilling the needs of Th-mining industry.

In this contribution, we attempt to expand the calculations reported in Migdisov et al. [3] by incorporating solid solution models for monazites/xenotimes and by accounting for the mobility of $U$ and $T h$ in aqueous solutions. We propose a first, though approximate, evaluation of the mechanisms that potentially can be responsible for natural separation of REE and actinides.

\section{Description of the model}

The model presented here simulates progressive hydrothermal alteration and re-distribution of $\mathrm{REE}, \mathrm{U}$, and Th by acidic solutions in a one-dimensional column of a rock containing $0.5 \mathrm{wt} \%$ apatite, which was evaluated using the step-flow reactor approach ("box-model"). The scenario evaluated in our model is illustrated in Figure 2. The initial event ("step 1") involved interaction and equilibration of a $1 \mathrm{~kg}$ aliquot of the solution carrying REE, U, and Th with $1 \mathrm{~kg}$ of rock, 


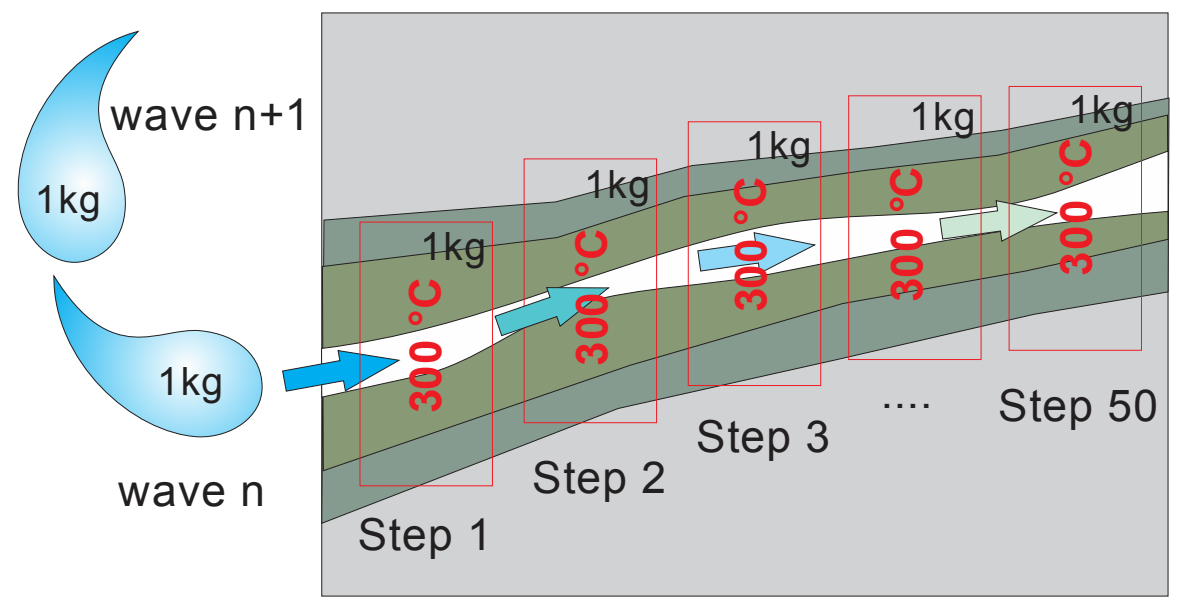

Figure 2. A sketch of the model calculated to evaluate fractionation of REE, $U$, and Th after interaction of a $10 \mathrm{wt} . \% \mathrm{NaCl}$ solution carrying these elements with a rock containing $0.5 \mathrm{wt} \%$ apatite

resulting in the deposition of monazite/xenotime minerals. This equilibrated fluid was moved to the second reactor where it was equilibrated with $1 \mathrm{~kg}$ of fresh, unaltered rock; the resulting fluid was subsequently moved to the next reactor once again containing $1 \mathrm{~kg}$ of fresh, unaltered rock.

105 This operation procedure was repeated 50 times, creating a column of rock altered by the first passage of the fluid aliquot ("wave 1"). After completion of the first "wave", a new portion of fluid $(1 \mathrm{~kg})$ of the same composition, was flushed through the already altered column in an identical manner ("wave 2"), as described above. The number of "waves" evaluated in the model ranged from 5 to 50 ; this computational technique is one of the simplest approaches to evaluate

110 the possibility for separation of REE, $\mathrm{U}$, and Th in systems continuously flushed by hydrothermal solutions, allowing for an investigation on the behavior of REE, $\mathrm{U}$, and Th at changing fluid/solid ratios. The models were formulated using the $\mathrm{HCh} /$ Unitherm code [13].

Calculations were performed at isothermal conditions of 250,300 , and $350{ }^{\circ} \mathrm{C}$. Temperature selection was based on fluid inclusion homogenization temperatures reported for known REE

115 deposits $[4,14-16]$. These studies suggest the temperature range of $250-500^{\circ} \mathrm{C}$, which broadly corresponds to the temperature interval of primary relevance for the hydrothermal transport and deposition of REE. However, we have restricted the model to $350{ }^{\circ} \mathrm{C}$ to avoid uncertainties associated with long-range temperature extrapolation of thermodynamic properties of aqueous species (see below). In order to avoid alteration of the observed trends by $\mathrm{pH}$, redox, and other

120 buffering parameters of the rock, the latter was assumed to be chemically inert and the only chemically active component of it was apatite. The composition of the solution was set based on compositions documented for solutions associated with natural REE ore forming systems. Fluid inclusion studies indicate that the Bayan Obo deposit in China was formed from brines containing 7 to $10 \mathrm{wt} . \% \mathrm{NaCl}$ equivalent [14]. The fluids responsible for ore deposition at 125 Gallinas Mountains contained 12 to 18 wt.\% NaCl equivalent [15], and the Karonge deposits formed from a brine containing $25 \mathrm{wt} . \% \mathrm{NaCl}$ equivalent [16]. To avoid uncertainties associated 
with poorly defined activity models for highly saline brines at elevated temperatures, the solution selected for calculations contained only $10 \mathrm{wt} . \% \mathrm{NaCl}(1.72 \mathrm{~mol} / \mathrm{kg})$ and simulated the scenario of re-distribution of REE, $U$, and Th by fluid containing $10 \mathrm{wt} . \% \mathrm{NaCl}$. Concentrations of REE in the solution associated with the initial depositional event ("step 1") were closely approximated to the composition of fluid inclusions from the Capitan Pluton REE mineralization (Table 1), documented by Banks et al. [4].These authors, however, did not report the concentrations of Y, the main component of xenotime solid solutions. Natural occurrence of Y varies significantly; in our calculations, the concentrations of this element were set to be one third of the concentrations of $\mathrm{La}$ and $\mathrm{Ce}$. Concentrations of $\mathrm{U}$ and $\mathrm{Th}$ in these solutions were fixed by their saturation with respect to uraninite $\left(\mathrm{UO}_{2}\right)$ and thorianite $\left(\mathrm{ThO}_{2}\right)$, respectively, at the temperature of calculations. The value of $\mathrm{pH}^{\mathrm{T}}$ of the initial solution was set at 2 [17] by adding appropriate amounts of $\mathrm{HCl}$. Considering that $\mathrm{U}$ is a highly redox sensitive element, the scenario discussed above was modelled at various redox conditions. The most reducing conditions considered in our model corresponded to the $\mathrm{Ni} / \mathrm{NiO}$ redox buffer: a typical redox condition encountered in reducing natural systems $\left(\log f \mathrm{O}_{2}=-38.06,-33.90\right.$, and -30.46 , at 250,300 , and $350{ }^{\circ} \mathrm{C}$, respectively). The oxidizing scenario incorporated redox conditions corresponding to the hematite/magnetite $\left(\mathrm{Fe}_{2} \mathrm{O}_{3} / \mathrm{Fe}_{3} \mathrm{O}_{4}\right)$ equilibrium $\left(\log f \mathrm{O}_{2}=-35.22,-30.9\right.$, and -27.0 , at 250,300 , and $350{ }^{\circ} \mathrm{C}$, respectively) or higher (e.g., $\mathrm{HM}+2: \log f \mathrm{O}_{2}=\log f \mathrm{O}_{2} \mathrm{HM}_{+2}$ ) - another redox state typical of

145 natural hydrothermal systems. However, Ni and Fe were not included in the chemical description of our system: redox conditions were set directly through the corresponding fugacity of $\mathrm{O}_{2}{ }^{\text {gas; }}$; in these calculations, oxygen did not obey the mass balance law and its behavior and content in the system were controlled by the chemical potential of $\mathrm{O}_{2}$ gas. Thus, for each temperature discussed above, calculations were performed for at least two scenarios: 1) starting solution of $10 \mathrm{wt} . \%$ $\mathrm{NaCl}$, reducing conditions $(\mathrm{Ni} / \mathrm{NiO})$, and 2) starting solution of $10 \mathrm{wt} \% \mathrm{NaCl}$, oxidizing conditions $(\mathrm{HM}+)$.

\section{Thermodynamic description of the system 3.1. Aqueous speciation}

155 A full list of aqueous species employed in the calculations, together with the parameters of equations of state used to extrapolate their properties to elevated temperature, as well as the data sources, is provided in the Electronic supplement to this paper. All calculations of equilibrium compositions conducted in this study employed Haar-Gallaher-Kell [18] and Marshall and Franck [19] models for calculation of the thermodynamic properties and dissociation constant of $\mathrm{H}_{2} \mathrm{O}$, respectively. The activities of the individual ions were calculated using the extended Debye-Hückel model modified by Oelkers et al. [20] and Oelkers and Helgeson [21] for NaCldominated solutions (recommended for up to $\mathrm{I}=6$ and $\mathrm{T}$ up to $600{ }^{\circ} \mathrm{C}$ ):

$$
\log \gamma_{i}=\frac{A \cdot\left[Z_{i}\right]^{2} \cdot \sqrt{I}}{1+B \cdot \dot{a} \cdot \sqrt{I}}+\Gamma+b_{\gamma} \cdot I
$$

where $\mathrm{A}$ and $\mathrm{B}$ are the Debye-Hückel solvent parameters, $\gamma_{\mathrm{i}}, \mathrm{Z}_{\mathrm{i}}$ and $\dot{a}_{i}$ are the individual molal activity coefficient, the charge, and the distance of closest approach of an ion $i$, respectively. The effective ionic strength calculated using the molal scale is $I, \Gamma$ is a molarity to molality conversion factor, and $b_{\gamma}$ is the extended-term parameter for $\mathrm{NaCl}$ from Oelkers et al. [20] and Oelkers and Helgeson [21]. 
Thermodynamic properties of basic aqueous species $\mathrm{O}_{2}{ }^{\mathrm{o}}$ aq, $\mathrm{H}_{2}{ }^{\mathrm{o}}$ aq $, \mathrm{Na}^{+}, \mathrm{NaOH}^{\mathrm{o}}{ }_{\mathrm{aq}}, \mathrm{NaHS}^{\mathrm{o}}$ aq, $\mathrm{NaSO}_{4}{ }^{-}, \mathrm{NaCl}^{\circ}{ }_{\text {aq }}$, and $\mathrm{Cl}^{-}$were taken from Johnson et al. [22], Shock et al. [23], and Sverjensky et al. [24]. The stability of $\mathrm{HCl}^{\circ}$ aq ion pair was evaluated using the combined data from Tagirov et al. [25] and Ho et al. [26]. Thermodynamic properties of $\mathrm{O}_{2}$ gas, which was used to control redox conditions in aqueous solutions, were taken from Holland and Powell [27]. The properties of simple hydrated ions $\mathrm{REE}^{3+}, \mathrm{Th}^{4+}, \mathrm{U}^{4+}$, and $\mathrm{UO}_{2}{ }^{2+}$ were taken from Shock et al. [23] and [28].

175 Aqueous complexes of REE: High temperature stability of aqueous REE complexes has been discussed in detail in Migdisov et al. [3]; thus for topics not covered in the following review the readers may refer to this publication.

The stability of hydroxyl complexes of REE were modeled using the data reported by Haas et al. [29]. It should be noted that at the acidic $\mathrm{pH}$ modelled in our calculations, these species do not contribute significantly to the mass balance of dissolved REE. Moreover, as shown by Wood et al. [30], the data reported in Haas et al. [29] likely overestimates the stability of hydroxyl complexes of REE at elevated temperatures, and therefore its actual contribution could be even lower. The data on the stability of chloride complexes of REE at elevated temperatures has been summarized in Migdisov et al. [3]. The available experimental studies have demonstrated that in 185 solutions containing up to $5 \mathrm{M} \mathrm{NaCl}$ at temperatures up to $300{ }^{\circ} \mathrm{C}$, the dominant REE chloride complexes are the mono- and dichloride species, $\mathrm{REECl}^{2+}$ and $\mathrm{REECl}_{2}{ }^{+}$. Figure 3 illustrates the inter-element dependencies of thermodynamic stability constants $\left(\beta^{\mathrm{Cl}}\right)$ for both of these complexes obtained

190 experimentally at different temperatures. It can be seen from this figure that the stability of REE chloride species increases with increasing temperature. For example, the stability of the LREE rises $\sim 2$ orders of 195 magnitude for a temperature increase from 150 to $250^{\circ} \mathrm{C}$. The data also shows that the LREE are more stable, and, thus, more mobile than the HREE in chloride-bearing aqueous solutions, and this difference in

200 stability increases with increasing temperature. Given that, in acidic solutions containing $10 \mathrm{wt} . \%$ (and higher) $\mathrm{NaCl}$, chloride complexes play a significant role in the mass balance of dissolved REE [3], 205 the higher stability of LREE complexes over HREE complexes is one of the main vehicles for separating LREE from HREE in hydrothermal processes. The stability of Y chloride complexes at hydrothermal

210 temperatures has not yet been determined experimentally nor evaluated theoretically. At ambient conditions, however, the stability of these species was found to be effectively indistinguishable from those
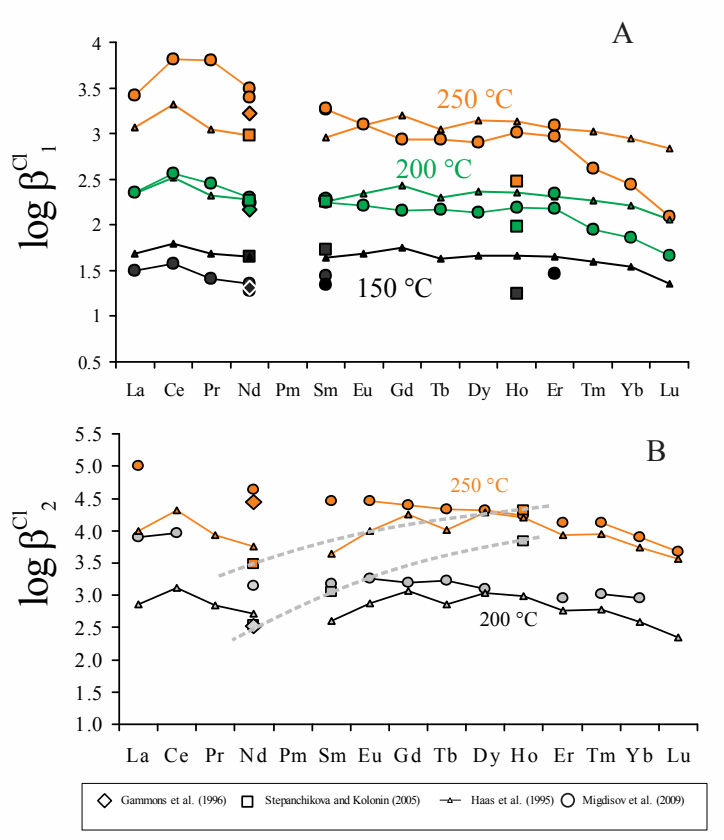

Figure 3. Comparison of the values of the first formation constants (A) and the second formation constants (B) of REE chloride complexes obtained experimentally [91-96] and predicted theoretically (triangles)[29]. 
215 determined for chloride complexes of Ho and Dy [31] (which is consistent with the similar ionic radii of these metals: $0.900,0.901$, and $0.912 \AA$ for $Y$, Ho, and Dy, respectively). Considering the latter, we modelled the behavior of $Y$ chloride complexes assuming them to be identical to Ho chloride complexes. It should be pointed out, however, that this assumption is a very rough first approximation, and that accurate modeling of the behavior of $\mathrm{Y}$ in $\mathrm{Cl}$-bearing solutions 220 requires the accumulation of an additional experimental dataset. The data reported in Migdisov et al. [3] is recommended for calculations up to $350{ }^{\circ} \mathrm{C}$; thus, the upper temperature range considered in our calculations was limited to this temperature.

Aqueous complexes of $U$ : During the past several years, a number of studies evaluating the thermodynamics of $U$ aqueous species have been published. Of these studies, a few have

225 theoretically or experimentally derived high temperature stability constants of U species [32-34]. The most recent summary of high temperature stability of U species was reported in [34], from which the majority of the data used in our calculations on the stability of U species were taken; for detailed information, the readers are referred to [34].

The stability of hydroxyl complexes of $U(I V)$ was calculated based on the data reported in Shock 230 et al. [28] and summarized in Wang et al. [33]. It should be noted that the derivation of these properties in Shock et al. [28] are primarily based on the experimental study of Parks and Pohl [35]. This study, however, only experimentally determined the stability of $\mathrm{UOH}^{3+}$ and $\mathrm{U}(\mathrm{OH})_{4}{ }^{\circ}$. Stability constants for other hydroxyl species of U(IV) were theoretically extrapolated by Shock et al. [28]. Notably, the values recommended by Parks and Pohl [35] were derived based on the

235 solubility of $\mathrm{UO}_{2}$ determined in Cl-bearing solutions at temperatures up to $300^{\circ} \mathrm{C}$ and strictly reduced conditions. Following the features observed at $25^{\circ} \mathrm{C}$, derivations of the properties of $\mathrm{UOH}^{3+}$ and $\mathrm{U}(\mathrm{OH})_{4}{ }^{\circ}$ were performed by the authors assuming ignorable complexation of U(IV) with chloride. However, the latter assumption is likely erroneous. As it was shown experimentally in Timofeev et al. [36], at $\mathrm{T} \geq 250{ }^{\circ} \mathrm{C}$ affinity of $\mathrm{U}(\mathrm{IV})$ to chloride increases

240 drastically, and in acidic $\left(\mathrm{pH}^{\mathrm{T}}=1.6-2.1\right)$ solutions having concentration of $\mathrm{NaCl}$ of $0.5-1.5$ $\mathrm{mol} / \mathrm{kg}$ the complex $\mathrm{UCl}_{4}{ }^{\circ}$ became the predominant species of U(IV) in aqueous solution. The study of Parks and Pohl [35] was performed at low concentrations of chloride

245 and involved $\mathrm{pH}^{\mathrm{T}}$, at which contribution of $\mathrm{UCl}_{4}{ }^{\circ}$ was significantly lower than that observed in the experiments of Timofeev et al. [36]. Nevertheless, there is still possibility that the data derived for $\mathrm{UOH}^{3+}$ (whose stability

250 was derived based on the measurements at low pHT, where chloride complexation might have effect) may overestimate the stability of this species at elevated temperatures.

The stability of chloride complexes of $U(I V)$

255 has been discussed in detail in Xing et al. [34]. The authors used an iso-coulombic extrapolation technique, where, based on the data available for $\mathrm{UF}^{3+}$ and $\mathrm{UF}_{2}{ }^{2+}[37,38]$ and low-T data for chloride species of U(IV)

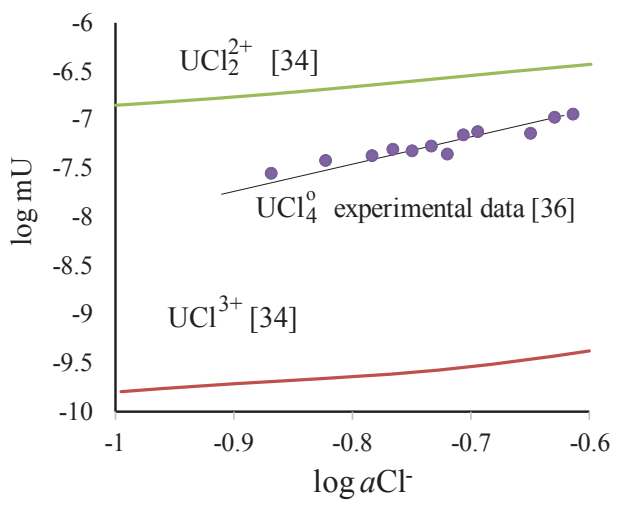

Figure 4. Comparison of predictions made based on the extrapolations reported in Xing et al. [34] with experimental data reported in Timofeev et al. [36] 
$260[37,38]$, they derived temperature dependence of the formation constants for $\mathrm{UCl}^{3+}$ and $\mathrm{UCl}_{2}{ }^{2+}$. In addition, experiments involving the determination of the solubility of $\mathrm{U}$ oxides in acidic $\mathrm{NaCl}$ solutions at controlled redox conditions [36] have recently revealed that the predominant chloride complex of $\mathrm{U}(\mathrm{IV})$ at $250-350{ }^{\circ} \mathrm{C}$ is $\mathrm{UCl}_{4}{ }^{\circ}$; a complex that has not been detected at ambient conditions. To account for this species in our calculations, the formation constants 265 reported in Timofeev et al. [36] for 250,300 , and $350{ }^{\circ} \mathrm{C}$ were fitted to the modified RyzhenkoBryzgalin model [39] (MRB); the parameters of this equation of state are listed in the summarizing Table available in the Electronic Supplement. In order to test the obtained dataset for U(IV)-chloride complexes, we have modeled species distribution in the system experimentally investigated in Timofeev et al. [36] (up to $1.5 \mathrm{~mol} / \mathrm{kg} \mathrm{NaCl}, 300{ }^{\circ} \mathrm{C}$, saturation 270 with respect to solid $\mathrm{UO}_{2}, \mathrm{Ni} / \mathrm{NiO}$ solid state redox buffer). Extrapolations of Xing et al. [34] suggest an predominance of $\mathrm{UCl}_{2}{ }^{2+}$ under the conditions of the experiments reported by Timofeev et al. [36], whereas the latter suggests the predominance of $\mathrm{UCl}_{4}{ }^{\circ}()$ and concentrations of dissolved $U$ lower than that predicted by extrapolations. Therefore, we conclude that the extrapolations of Xing et al. [34] overestimate the stability of $\mathrm{UCl}_{2}{ }^{2+}$ and thus we did not account 275 for this species in our calculations.

Experimental studies have identified a large variety of uranyl-hydroxide complexes at ambient conditions [32,33]. These include a range of mono-nuclear species varying from $\mathrm{UO}_{2} \mathrm{OH}^{+}$to $\mathrm{UO}_{2}(\mathrm{OH})_{4}{ }^{2-}$, and a range of poly-nuclear species varying from $\left(\mathrm{UO}_{2}\right)_{2}(\mathrm{OH})_{2}{ }^{2+}$ to $\left(\mathrm{UO}_{2}\right)_{4}(\mathrm{OH})_{7}{ }^{+}$. The properties of these complexes were

280 reviewed and extrapolated to elevated temperatures in [34]. The authors [34] noted that their extrapolations suggest the stability of poly-nuclear complexes decrease with increasing temperature. The latter conclusion 285 is in qualitative agreement with our recent experimental findings for the behavior of Th hydroxyl complexes [40]. The stability of uranyl-chloride complexes was modeled based on the formation constants obtained 290 experimentally using in situ high-T UV-Vis spectroscopy [41] and solubility techniques [36] at temperatures up to $350{ }^{\circ} \mathrm{C}$. These data

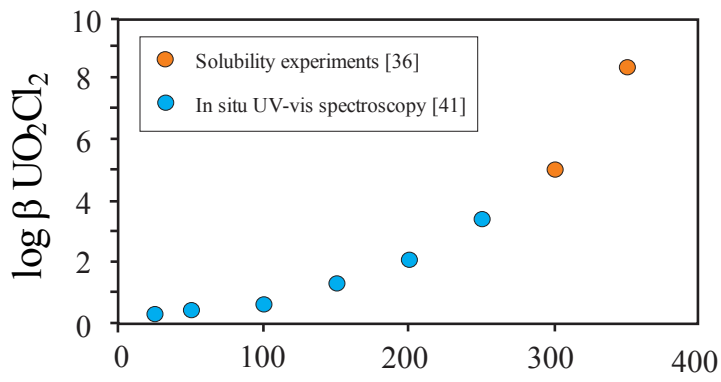

Figure 5. Comparison of the values of formation constants for $\mathrm{UO}_{2} \mathrm{Cl}_{2}$ complex obtained using in situ UV-vis spectroscopy [41] and autoclave solubility technique [36] indicate that at the conditions of our calculations, chloride speciation of uranyl is controlled by the complexes $\mathrm{UO}_{2} \mathrm{Cl}^{+}$and $\mathrm{UO}_{2} \mathrm{Cl}_{2}{ }^{\circ}$;

295 the latter becoming predominant at $\mathrm{T}>150-200^{\circ} \mathrm{C}$. In spite of using significantly different experimental techniques in Migdisov et al. and Timofeev et al. [36,41], the data collected are in perfect agreement (). This agreement permits us to assume reasonably good accuracy of the recommended values of formation constants. That said, it should be noted that this dataset is in significant disagreement with a study performed using the Raman spectroscopic technique [42], 300 suggesting much higher affinity of uranyl to chloride and the development of high level chloride species, such as $\mathrm{UO}_{2} \mathrm{Cl}_{3}{ }^{-}, \mathrm{UO}_{2} \mathrm{Cl}_{4}{ }^{2-}$, and $\mathrm{UO}_{2} \mathrm{Cl}_{5}{ }^{3-}$. Nevertheless, taking into account that the speciation model proposed by Dargent et al. [42] has not been confirmed by the study conducted using UV-visible spectroscopy [41], nor the solubility study using the autoclave technique [36], we conclude that the stability constants reported in Dargent et al. [42] are likely overestimated and thus we do not consider them here (for a more detailed discussion on this subject, readers are 
referred to Migdisov et al. [43]). Although we do not exclude the possibility that these species may contribute to the mass balance of dissolved $\mathrm{U}$ at higher concentrations of $\mathrm{NaCl}$, at the conditions considered in our calculations, their occurrence at significant levels is unlikely.

Aqueous complexes of Th: Information on the stability of aqueous species of Th is much sparser than that available for $U$. The main source of data currently available is [44]. This compilation however reports stability constants derived only for temperatures below $100{ }^{\circ} \mathrm{C}$ : to the best of our knowledge, the only paper to report the formation constants for aqueous complexes of Th at hydrothermal conditions is our recent experimental study [40] on the solubility of $\mathrm{ThO}_{2}$ in solutions of variable $\mathrm{pH}\left(\mathrm{pH}^{\mathrm{T}}=1.5-3.5\right)$ and $\mathrm{NaCl}$ concentrations $(0-2.5 \mathrm{~mol} / \mathrm{kg})$ at

315 temperatures up to $250^{\circ} \mathrm{C}$. Thus, the calculations reported in this contribution are based on high$\mathrm{T}$ extrapolations from the data reported in [44] and the stability constants derived in [40].

At ambient conditions, a number of $T h$ -

320 hydroxyl complexes $\left(\mathrm{Th}_{\mathrm{x}}(\mathrm{OH})_{\mathrm{y}}{ }^{4 \mathrm{x}-\mathrm{y}}\right)$, including monomeric $(1,1),(2,1),(3,1)$ and $(4,1)$ species; dimeric $(1,2),(2,2),(3,2),(4,2)$ and $(7,2)$ species; trimeric $(3,3),(5,3)$ and $(6,3)$ species; tetrameric $(8,4)$ and $(12,4)$ species; 325 and hexameric $(14,6)$ and $(15,6)$ species, have been reported in [45]. The degree of contribution of poly-nuclear species to the mass balance of dissolved Th is, however, still under debate: differences in

330 experimental methods, the range of Th concentrations and the ionic media used have made it difficult, if not impossible, to select and interpret the data needed to produce the "best" chemical model[45-48]. Our high

335 temperature study [40], however, suggests that the contribution of poly-nuclear complexes decreases drastically with temperature, and that at $\mathrm{T}>150^{\circ} \mathrm{C}$, the predominant hydroxyl complexes of Th are 340 mono-nuclear $\mathrm{Th}(\mathrm{OH})_{2}{ }^{2+}$ and $\mathrm{Th}(\mathrm{OH})_{4}{ }^{\circ}$. In
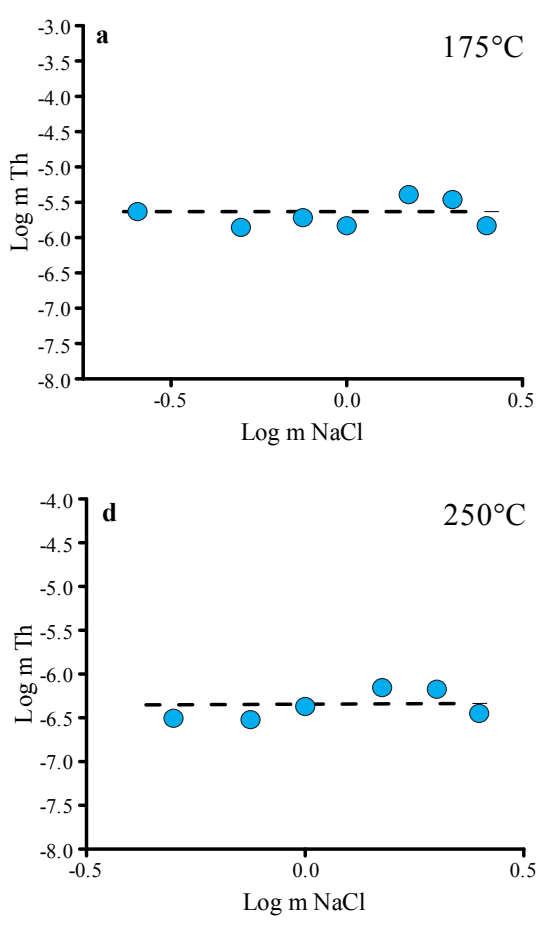

Figure 6. Solubility of $\mathrm{ThO}_{2}$ determined as a function of increasing $\mathrm{NaCl}$ content [40] at (a) 175 , (b) $250^{\circ} \mathrm{C}$. our calculations, complexation of Th with hydroxyl was thus modeled with these species using the recommended formation constants fitted to the MRB model. This study [40] has also demonstrated that the contribution of Th chloride complexes to the mass balance of dissolved Th

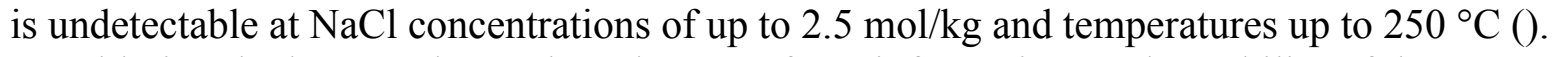

345 Considering the latter and complete absence of any information on the stability of these complexes at elevated temperatures, chloride complexes of Th were not considered in our calculations.

\subsection{Solid phases}

Thermodynamic properties of pure phases and solid solution end-members: The model reported in this contribution primarily focuses on the behavior of REE, U, and Th in phosphate solid 
solutions and co-existing aqueous species. In addition, the model also needs to account for the coexisting uraninite $\left(\mathrm{UO}_{2}\right), \mathrm{U}_{3} \mathrm{O}_{8}$ and $\mathrm{U}_{4} \mathrm{O}_{9}[37,38]$, thorianite $\left(\mathrm{ThO}_{2}[49]\right)$, solid REE hydroxides[3], apatite- $\mathrm{OH}$ and whitlockite $\left(\mathrm{Ca}_{5}\left(\mathrm{PO}_{4}\right)_{3} \mathrm{OH}\right.$ and $\left.\mathrm{Ca}_{3}(\mathrm{PO} 4)_{2}\right)$, halite $(\mathrm{NaCl})$, hydrophilite $\left(\mathrm{CaCl}_{2}\right)$, and portlandite $\left(\mathrm{Ca}(\mathrm{OH})_{2}\right)$ [49]. Except for $\mathrm{U}$ and Th oxides, apatite-OH, 355 and whitlockite, all other phases listed above were found unstable under the conditions employed in our model.

Thermodynamic properties of pure REE-phosphate end-members have been summarized in Migdisov et al. [3]. The data for monazite end-members $\left(\mathrm{LaPO}_{4}\right.$ to $\left.\mathrm{GdPO}_{4}\right)$ were derived based on the calorimetric measurements by Navrotsky et al. and Popa et al. [50-52] and the values of 360 solubility products determined for REE phosphates at $25^{\circ} \mathrm{C}$ by Liu and Byrne [53]. The obtained dataset was tuned against the available solubility product of Nd-monazite endmember at temperatures up to $300^{\circ} \mathrm{C}$ [54]. It was found that the derived dataset

365 satisfactorily reproduces the high temperature solubility data [54]; it was however also found that higher temperature data reported by Pourtier et al. [55] drastically disagrees with both the 370 derived thermodynamic properties of $\mathrm{NdPO}_{4}$ and experimental determinations of its solubility product at lower temperatures (). Considering that the data reported in Pourtier et al. [55] do not

375 agree with low-T determinations of the solubility product, calorimetric measurements, and experimental data reported in Poitrasson et al. [54], the data from Pourtier et al. [55] were

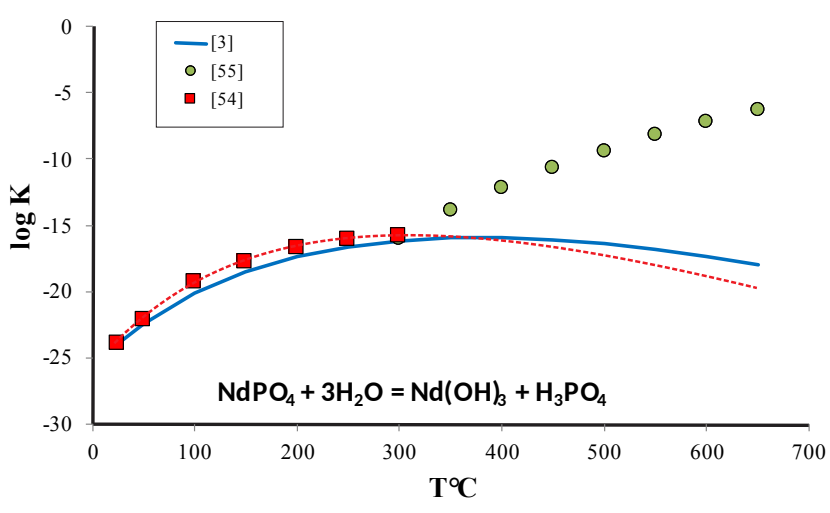

Figure 7. Comparison of the values of the dissolution equilibrium constant for $\mathrm{Nd}$ phosphate, re-calculated from the experimental data of Poitrasson et al. [54], calculated using the data summarized in [3], and experimentally determined by Pourtier et al. [55]

380 disregarded. Thermodynamic properties for xenotime end-members $\left(\mathrm{YPO}_{4}\right.$, and $\mathrm{TbPO}_{4}$ to $\mathrm{LuPO}_{4}$ ) were derived based on the calorimetric data reported in Navrotsky et al. and a set of studies of Gavrichev et al. [52,56-60], and, similarly to monazites, on the values of the solubility products reported for $25^{\circ} \mathrm{C}$ [53]. The obtained dataset is in excellent agreement with the experimentally determined [61] solubility products of xenotimes at temperatures up to $250{ }^{\circ} \mathrm{C}$ 385 (Figure 8).

The incorporation of actinides (U, Th) in monazites or xenotimes has been documented to occur via charge-couple ionic substitutions [7,62-66] (Fig. 1): the brabantitic (or cheralite, $\left.\mathrm{Ca}_{0.5} \mathrm{Th}_{0.5} \mathrm{PO}_{4}\right)$ substitution (2) or the huttonite $\left(\mathrm{ThSiO}_{4}\right)$ substitution (3), as expressed below:

$2 \mathrm{REE}^{3+} \leftrightarrow(\mathrm{U}, \mathrm{Th})^{4+}+\mathrm{Ca}^{2+}$

$\mathrm{REE}^{3+}+\mathrm{P}^{5+} \leftrightarrow(\mathrm{U}, \mathrm{Th})^{4+}+\mathrm{Si}^{4+}$

The brabantitic substitution (2) occurs over the REE site while the huttonite substitution (3) occurs over both the REE and P tetrahedral sites. Because of the lack of experimental data related to substitution (3), our models focus on substitution (2), where the extra charge introduced by the tetravalent $\mathrm{An}$ is accommodated via incorporation of $\mathrm{Ca}^{2+}$ into the structure. It 

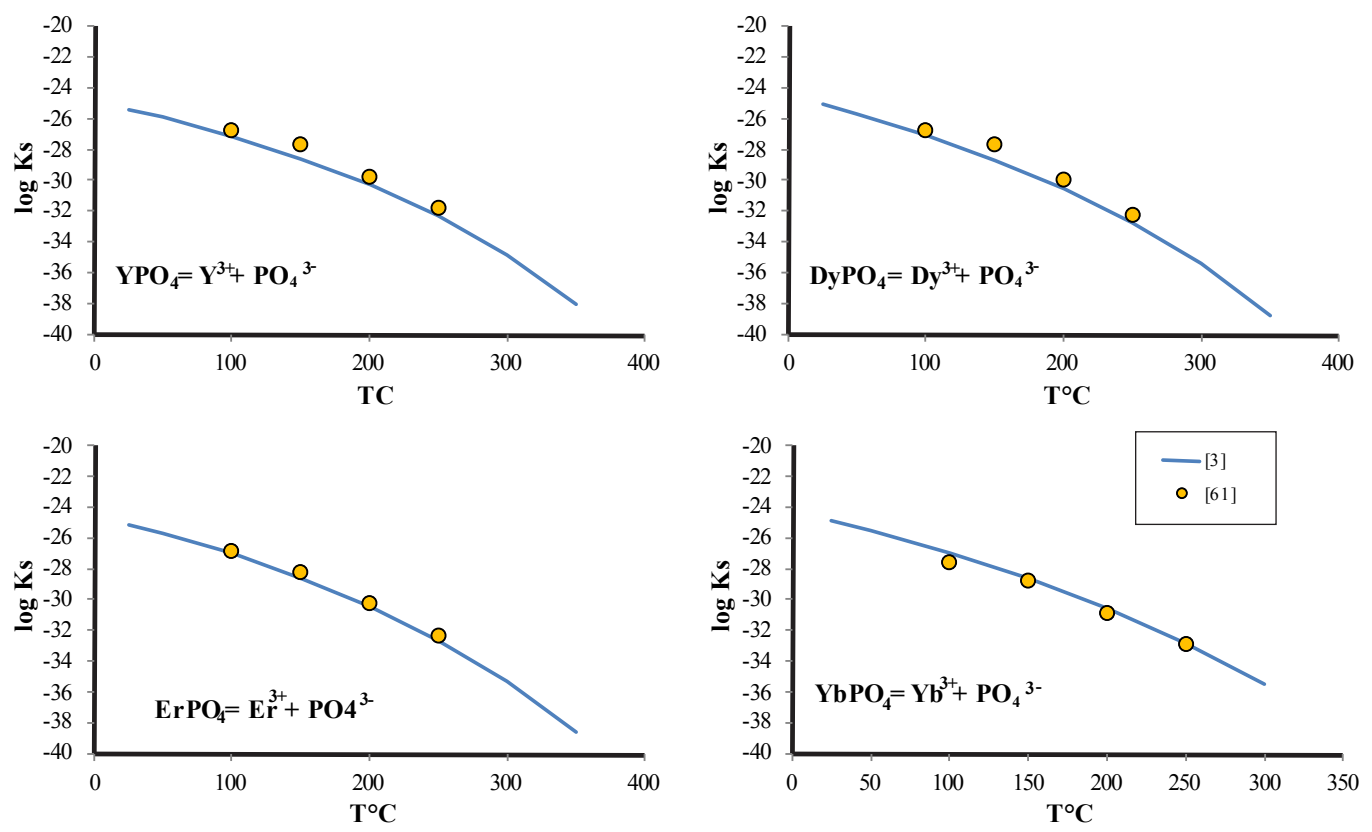

Figure 8. Comparison of the values of the solubility products for xenotime obtained experimentally by Gysi et al. [61], with those calculated based on the data summarized in [3]

395 should be pointed out that our inability to account for substitution (3) may lead to additional uncertainty associated with the trends described in our model. Thermodynamic properties of pure ( $\mathrm{Ca}, \mathrm{Th}) \mathrm{PO}_{4}$ end-member were taken from [67,68]. Information on the properties of pure $(\mathrm{Ca}, \mathrm{U}) \mathrm{PO}_{4}$ end-member is much sparser and is restricted to the Gibbs free energy of formation determined by Muto [69] at $25^{\circ} \mathrm{C}$. Considering that the averaged mass of the (Ca, U)

400 substituting pair is identical to that of $\mathrm{La}$ (139), to the first approximation, we assumed that the changes in $\Delta \mathrm{G}_{f}^{\circ}$ for $(\mathrm{Ca}, \mathrm{U}) \mathrm{PO}_{4}$ with temperature, and, thus, the values of entropy and temperature dependence of heat capacity are identical to those for $\mathrm{LaPO}_{4}$. Though reasonable, this is a rough approximation, thereby needing future verification.

Mixing properties of monazite and xenotime solid solutions: The mixing behavior of REE in the 405 monazite and xenotime structures has been investigated from both experimental and computational perspectives. For solid solutions, depending on their free energy, enthalpy and entropy of mixing, they may form ideal solution, regular solution and subregular solution, the latter two of which require introduction of an interaction parameter to describe their mixing behavior.

410 To determine the mixing systematics of L/MREE in monazite and HREE in xenotime, we employed a regular solid solution model in which the excess enthalpy of mixing $\Delta H^{\mathrm{E}}{ }_{\text {mix }}$ is expressed as $W \cdot x(1-x)$, where $W$ is the interaction parameter and $x$ is the portion of one REE over the cation site. Calorimetric techniques have been used to determine $W$ values of various solid 
solution systems with good precisions, as demonstrated by previous high-temperature oxide-melt drop-solution calorimetric studies of spinel, yttrium stabilized zirconia, silicates, titanates and niobates [70-75]. However, only a few phosphate systems have been studied calorimetrically with the exception of La-Ln(-An) phosphates [76-80], and thus there is a knowledge gap in understanding the mixing behavior of REE monazite and xenotime solid solutions from experimental data. Kowalski and Li [81], and Mogilevsky [82] tried to fill this gap using $a b$ 420 initio calculations implemented with models linking the mixing energetics with lattice energy strains; they proposed the main contributor to the excess mixing properties of two REE in monazite to be the strain energy originated from the mismatch of these two different REE cations in the nine-coordinated (monazite) or eight-coordinated (xenotime) sublattices. Specifically, the Margules interaction parameters can be expressed as a function of the volume mismatch from the two end-members and are proportional to the average Young's modulus $\bar{E}$ :

$$
W=\bar{E} \cdot\left(\Delta \mathrm{V}^{2} / 6 \mathrm{~V}\right) .
$$

For modelling the monazite system, we used interaction parameters (Table 2) that were obtained from calorimetric measurements or from theoretical calculations $[78,81]$ by Kowalski and Li based on the available experimentally measured Young's moduli and molar volumes of end430 members. As for the xenotime system, the Young's moduli $(E)$ and thus interaction parameters $(W)$ are largely unknown. Instead, Mogilevsky estimated $E$ values of monazites and xenotimes from the ionic radii $R$ of the cations, and found a near linear correlation [82]. We assessed such correlation with known and newly available elastic constants data [83-85] and plotted them in Figure 9.

435 The new $E_{x}-R_{x}$ function for xenotime is:

$$
E_{x}=1320.4( \pm 179.6)-1142.8( \pm 178.0) \cdot R_{x} .
$$

From the $R_{x}$ for all of HREE (Tb

$\rightarrow$ Lu and Y), we calculated each of their $E_{x}$ based on equation (5).

440 The average Young's modulus and molar volume for xenotimes were calculated to be $\overline{E_{x}}=168.8$ $\mathrm{GPa}$ and $\overline{V_{x}}=42.520 \mathrm{~cm}^{3} / \mathrm{mol}$. Next, we determined $W_{x}$ in terms 445 of $\Delta \mathrm{V}, \overline{E_{x}}$ and $\overline{V_{x}}$ based on equation (4), plotted in Figure 10. As demonstrated previously by Glynn [86], in order for a solidsolution system to be 450 thermodynamically stable, the interaction parameter needs to be constrained by $W /\left(K_{B} \mathrm{~T}\right)<2$, which translates to $\mathrm{W}<5 \mathrm{~kJ} / \mathrm{mol}$ under the ambient condition. All 455 the calculated $W_{x}$ values are well below $5.0 \mathrm{~kJ} / \mathrm{mol}$, indicating that

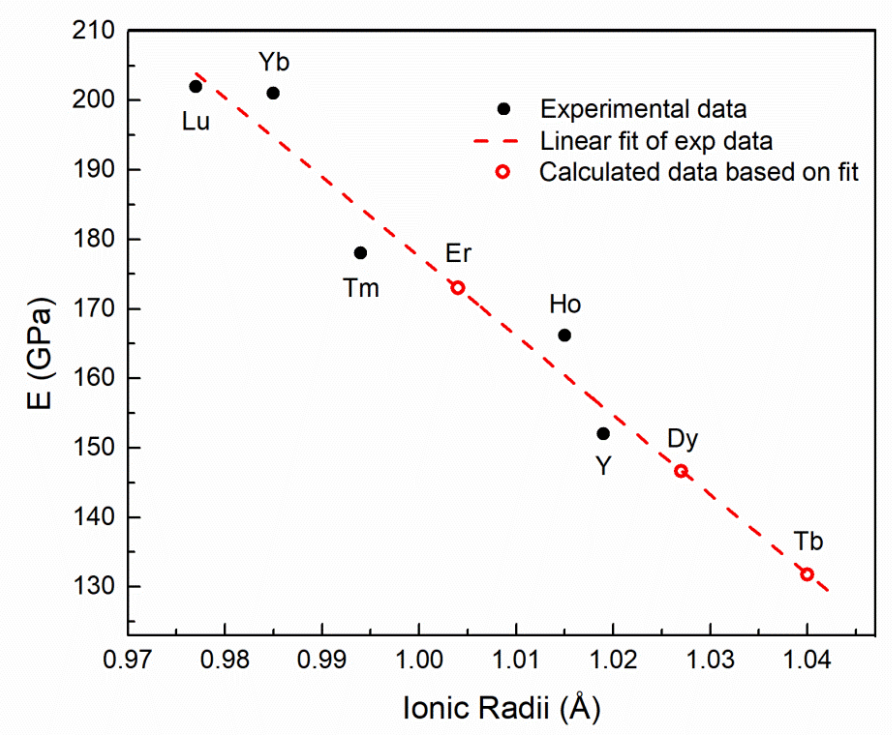

Figure 9. The correlation of Young's moduli $E_{x}$ with eightcoordinated ionic radii $R_{x}$ in the xenotime matrix. A near linear relation (red dash curve) was revealed based on known experimental $E_{x}$ data (black solid dots), which was used to calculate $E_{x}$ (red circle) for other HREE. 
there are no miscibility gaps for HREE solid-solutions in the xenotime structure. We evaluated the size of the pseudo cation $(\mathrm{Ca}, \mathrm{An})$ pair by averaging their eight-coordinated ionic radii, 1.085 and $1.060 \AA$, for $(\mathrm{Ca}, \mathrm{Th})$ and $(\mathrm{Ca}, \mathrm{U})$, respectively. Fitted by the function plotted in Figure 10 , the calculated $W_{x}$ values for $(\mathrm{Ca}, \mathrm{Th})$ and $(\mathrm{Ca}, \mathrm{U})$ are also listed in Table 3 . Note that although the $W_{x}$ values for $(\mathrm{Ca}, \mathrm{Th})$ and $(\mathrm{Ca}, \mathrm{U})$ are generally large, they could still be underestimated because, despite the average charge for the cation-pair being trivalent, each divalent $\mathrm{Ca}$ or tetravalent U/Th cation locally occupies an individual site, generating additional Coulombic interactions with its nearest (or next to the nearest) neighbors that could distort the sublattices, leading to an increase of the excess mixing enthalpy.

The most common monazites occurring in nature are monazite-(Ce) and monazite(La). Monazite-(Nd) is also found in natural systems but is much rarer. Thus, in

470 our model we accounted for two types of monazite: monazite-(Ce), containing $\mathrm{CePO}_{4}, \mathrm{PrPO}_{4}, \mathrm{NdPO}_{4}, \mathrm{SmPO}_{4}, \mathrm{GdPO}_{4}$, $(\mathrm{Ca}, \mathrm{Th}) \mathrm{PO}_{4}$, and $(\mathrm{Ca}, \mathrm{U}) \mathrm{PO}_{4}$, and monazite(La), containing $\mathrm{LaPO}_{4}, \mathrm{PrPO}_{4}, \mathrm{NdPO}_{4}$,

$475 \mathrm{SmPO}_{4}, \quad \mathrm{GdPO}_{4}, \quad(\mathrm{Ca}, \mathrm{Th}) \mathrm{PO}_{4}, \quad$ and $(\mathrm{Ca}, \mathrm{U}) \mathrm{PO}_{4}$. This separation into two types of monazites is necessary, also due to limitations of the software $(\mathrm{HCh})$, which cannot account for solid solutions having 480 more than 7 components. Formation of monazite-(Nd) was assumed when $\mathrm{NdPO}_{4}$ was predominated in one of the above solid solutions. Xenotime was defined in the model as the solid solution containing $485 \mathrm{YPO}_{4}, \mathrm{TbPO}_{4}, \mathrm{DyPO}_{4}, \mathrm{ErPO}_{4}, \mathrm{YbPO}_{4}$, $(\mathrm{Ca}, \mathrm{Th}) \mathrm{PO}_{4}$, and $(\mathrm{Ca}, \mathrm{U}) \mathrm{PO}_{4}$.

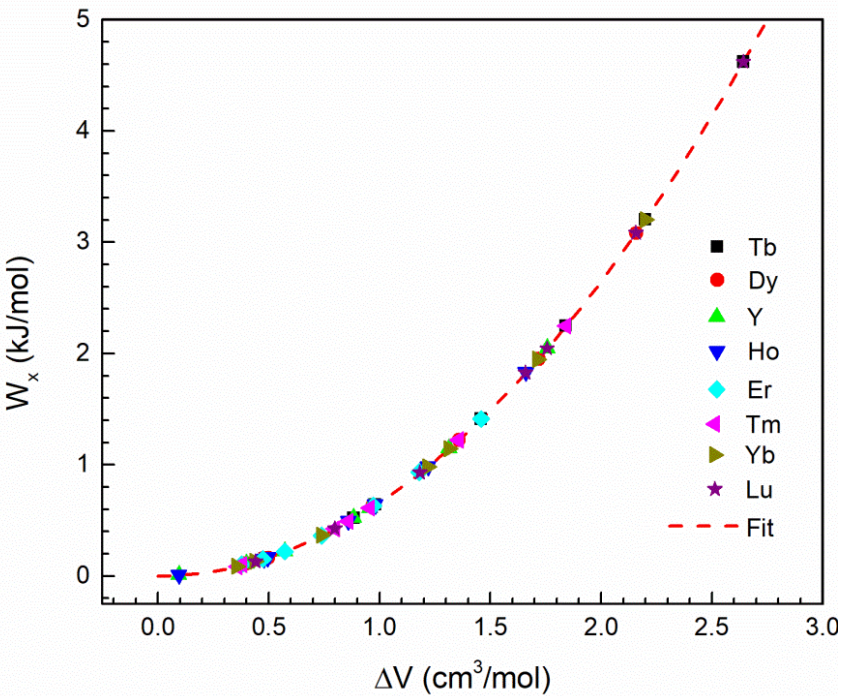

Figure 10. The fitted correlation between the interaction parameters $W_{x}$ and the difference molar volume $\Delta \mathrm{V}$, with selected calculated points for HREE endmembers

\section{Results}

\subsection{Aqueous speciation}

The selected range of $\mathrm{pH}^{\mathrm{T}}$ for the solutions in our calculations $\left(\mathrm{pH}^{\mathrm{T}} \leq 2\right)$ reflects the conditions documented for Strange Lake, Canada, a natural ore forming system [17]. Our previous models $[3,87]$ suggest that at these $\mathrm{pH}$ conditions and in NaCl-rich solutions, REE speciation is strictly predominated by chloride complexes. Differences in stability between LREE and HREE chloride

495 complexes, which start developing as temperatures increase, is a main mechanism for natural REE separation.

As expected, speciation of the REE in our model was overwhelmingly predominated by chloride complexes. An example of the changes in species distribution with temperature at the initial stage of interaction of REE-bearing solution with apatite-bearing rock is shown in Figure 11 for Y, La, Nd, and Er (Y, LREE, MREE, and HREE, respectively). Regardless of a change in total 
REE concentration at following interactive stages, the species distribution remains the same due to the constant concentration of chloride. The mass balance of REE dissolved in aqueous solution was primarily controlled by the bichloride complex, $\mathrm{REECl}_{2}{ }^{+}$, for LREE, the bichloride and 510 monochloride complexes, $\mathrm{REECl}_{2}{ }^{+}$ and $\mathrm{REECl}^{2+}$, respectively, for MREE, and by monochloride complexes for HREE. The only exception from this trend is $\mathrm{Y}$

515 whereby the data used in our calculation suggests that $\mathrm{Y}^{3+}$ contributes significantly to the mass balance of dissolved $\mathrm{Y}$, being the predominant species at $\mathrm{T}<300$
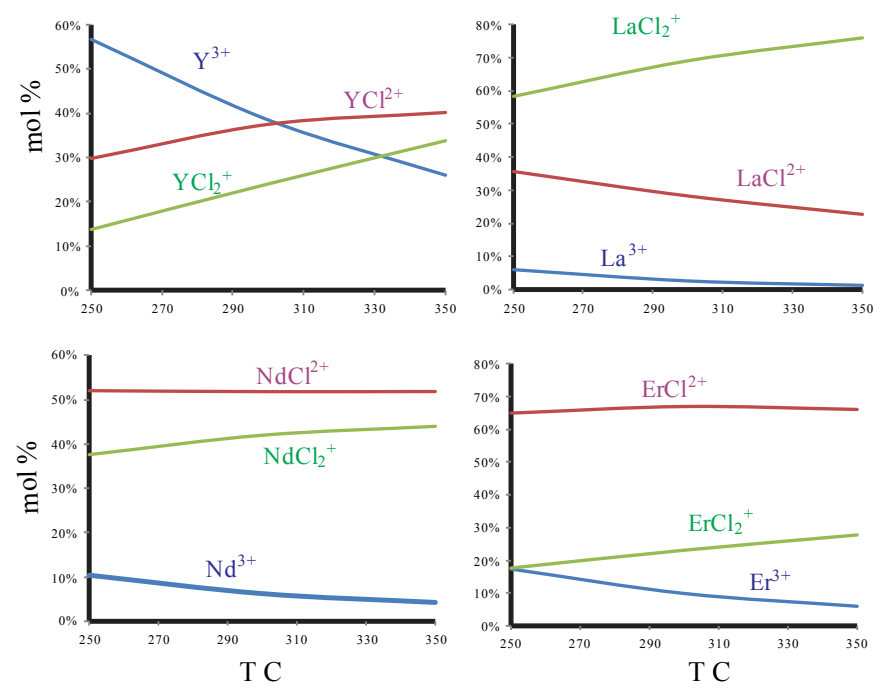

Figure 11. Distribution of predominant species of REE as a function of temperature $(10 \mathrm{wt} \% \mathrm{NaCl})$

$520{ }^{\circ} \mathrm{C}$ (Figure 11a). This could potentially be an artifact of our approximate evaluation of the properties of Ychloride species. Thus, again we remind the readers that due to the complete absence of data on these species, we assumed identical properties to those of 525 Ho-chloride complexes. Evidently, this assumption may eventually be erroneous and further refinement of the properties of Y-chloride complexes is needed.

Similarly to the REE, speciation of $U$ was predominated by chloride complexes, while sulfate 530 complexes did not contribute significantly to the mass balance of dissolved $U$, at both reducing and oxidizing conditions. Under reducing conditions the predominant U-bearing species is $\mathrm{UCl}_{4}{ }^{\circ}$, whereas at oxidizing conditions most of the $U$ is present as

$535 \mathrm{UO}_{2} \mathrm{Cl}_{2}^{\circ}$. Figure 12 illustrates the $\mathrm{U}$ species distribution returned by the model. Surprisingly, the stability of $\mathrm{UCl}_{4}{ }^{\circ}$ was found to contribute significantly $(10-20 \%)$ to the mass balance of dissolved U, even under oxidizing conditions. Despite its

540 counterintuitiveness, this finding is not entirely new: the high stability of $\mathrm{UCl}_{4}{ }^{\circ}$ at elevated temperatures has previously been discussed in Timofeev et al. [36]. Similarly, under reducing conditions, $\mathrm{UO}_{2} \mathrm{Cl}_{2}{ }^{\circ}$ also contributes at low level to the mass balance of dissolved U. Concentrations of total dissolved $U$ in reducing and oxidizing systems differ by $\sim 2$ orders of
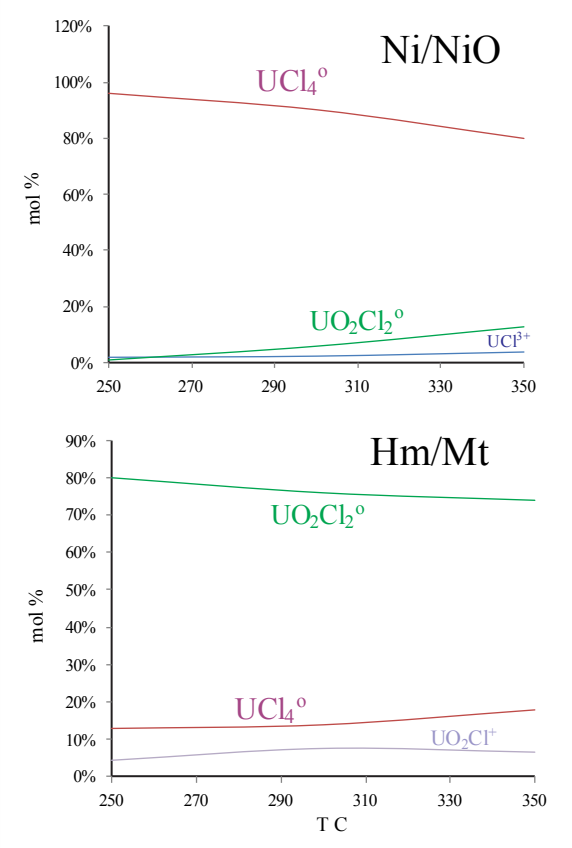

Figure 12. Distribution of predominant species of $U$ as a function of temperature in $10 \mathrm{wt} \%$ $\mathrm{NaCl}$ solution in systems buffered by $\mathrm{Ni} / \mathrm{NiO}$ redox buffer (a) and Hematite/Magnetite $\left(\mathrm{Fe}_{2} \mathrm{O}_{3} / \mathrm{Fe}_{3} \mathrm{O}_{4}\right)$ redox buffer (b) 
magnitude at $250{ }^{\circ} \mathrm{C}$, while this difference reduces to one order of magnitude at $350{ }^{\circ} \mathrm{C}$. Such small differences in total solubility of $\mathrm{U}$ are also due to the high stability of $\mathrm{UCl}_{4}{ }^{\circ}$, as also discussed in Timofeev et al. [36]. Analogous to the REE, the distribution of U species remains consistent, while the total concentration of $U$ changes when the fluid passes through the column - a result of continual high concentrations of $\mathrm{NaCl}$ in the solution.

Speciation of Th differs significantly from that of REE and U. The experiments reported by Nisbet et al. [40] did not reveal any contribution of Th chloride complexes in solutions with concentrations of $\mathrm{NaCl}$ up to $2.5 \mathrm{~mol} / \mathrm{kg}$ and temperatures up to $250{ }^{\circ} \mathrm{C}$. Thus, our model did not 555 account for these species. The only complex controlling the solubility of Th was $\mathrm{Th}(\mathrm{OH})_{2}{ }^{2+}$. Considering that the mobility of Th in the modeled solutions is controlled by hydroxyl complexes, its species distribution must be $\mathrm{pH}$-dependent. It should be noted that the $\mathrm{pH}^{\mathrm{T}}$ values of the solutions passing through the column shifts from an 1.9-2.0 to 2.5-2.8 due to the buffering effect from the interaction of acidic fluid with apatite. These $\mathrm{pH}^{\mathrm{T}}$ changes, however, are not

560 significant enough to change the predominant Th complex in the solution, as the other hydroxyl species described to control the mobility of Th in NaCl-bearing solutions in Nisbet et al. [40], $\mathrm{Th}(\mathrm{OH})_{4}{ }^{\circ}$, predominates only at $\mathrm{pH}^{\mathrm{T}} \geq 3$.

Examples of changes in total concentrations of dissolved metals along the column are shown in . The patterns obtained for REE

565 are similar to those reported previously $[3,87]$. The initial depositional event, i.e., the first contact of the REE-bearing solution with rock containing

570 excess apatite, causes quick deposition of effectively all the REE solution load in the form of highly insoluble xenotime and monazites. This continues

575 until the apatite content in the rock is exhausted. The following aliquots of the REEbearing solution re-equilibrates with previously deposited REE 580 phosphates. Significantly higher stability of LREE chloride complexes, compared to the HREE complexes, leads to the preferential deposition of HREE 585 phosphates at the expense of LREE phosphates:
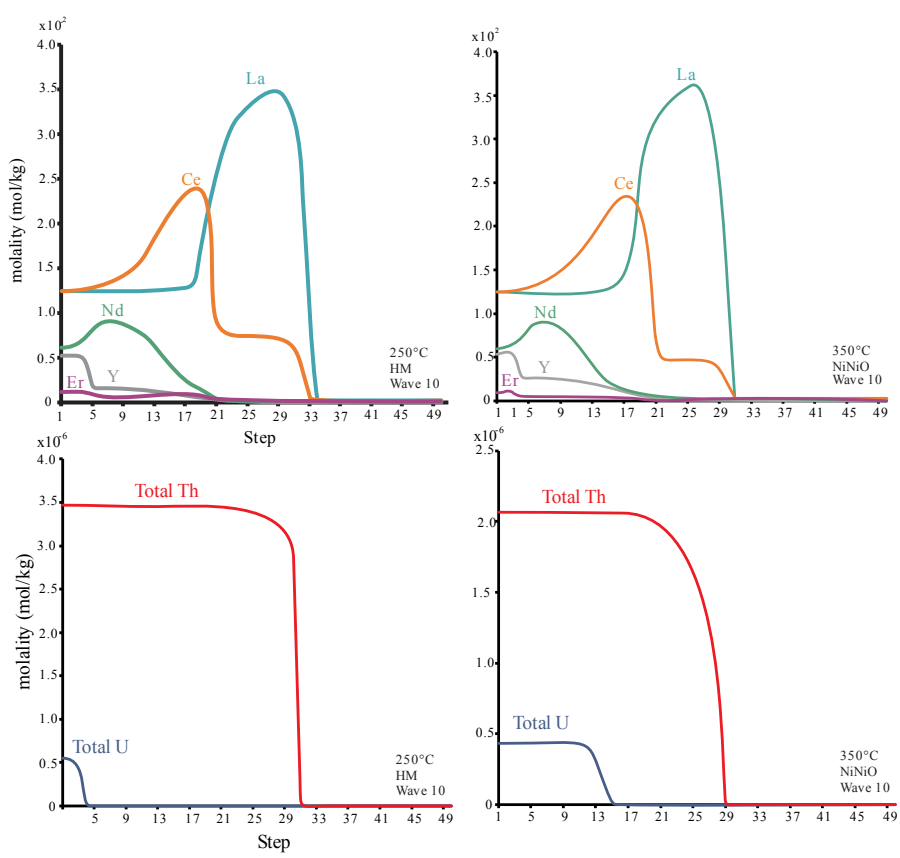

Figure 13. Distribution of total concentrations of REE, U, and $\mathrm{Th}$ in aqueous solution observed in the model along the column

$$
\mathrm{LREEPO}_{4}{ }^{\text {solid }}+\mathrm{HREECl}^{2+}+\mathrm{Cl}^{-}=\mathrm{HREEPO}_{4}{ }^{\text {solid }}+\mathrm{LREECl}_{2}{ }^{+}
$$

As a result of this process, LREE become re-mobilized by the solution, and concentrations of these elements steadily increase along the altered part of the column, whereas the concentrations of HREE quickly decrease due to continuous deposition of solid HREE phosphates. In the case of La, this process manifests itself to an extreme pattern: as it can be seen from Figure 13, La 
forms a concentration peak at the front of alteration. These distribution patterns of REE were observed at all temperatures in the conditions tested.

Surprisingly, although $U$ is expected to behave in significantly different ways in reducing and oxidizing systems, the patterns observed for total concentrations of $U$ are very similar for both types of systems. The U load in the solution quickly drops at the beginning of the column, reducing its concentration to insignificant levels. Continuous flushing of the system with Ubearing solution partially mobilizes $U$, however this happens with significant delay compared to other elements. This observed outcome can be described as solid solution-controlled, as further discussed next.

Due to the high stability of $\mathrm{Th}(\mathrm{OH})_{2}{ }^{2+}$ species, concentrations of Th initially developed in the solutions (re-equilibration with $\mathrm{ThO}_{2}{ }^{\text {solid }}$ ) are approximately one order of magnitude greater than that for $U$ even at oxidizing conditions, but still 4 to 5 orders of magnitude lower than that developed by REE (Figure 13). Thorium concentration remains steady in altered, apatite-

605 depleted rock, and begins decreasing near, and abruptly drops at the alteration front. This quick decrease at the alteration front is associated with two concordant processes: 1) the decrease of $\mathrm{pH}$ from 1.9 to $\sim 2.5-2.7$ due to interaction of acidic solution with apatite, which decreases the stability of $\mathrm{Th}(\mathrm{OH})_{2}{ }^{2+}$ in solutions saturated with respect to Th oxide, and 2) the incorporation of Th in solid solutions, which will be discussed below.

\subsection{Solid solutions}

Initial contact of the solutions with the apatitebearing rock results in intensive precipitation of REE, $U$, and $T h$ in the form of monazite and xenotime. Considering the near complete removal

615 of REE, U, and Th from the solutions at the initial stage (excess of apatite), the initial ratio of REE, $(\mathrm{Ca}, \mathrm{U})$, and $(\mathrm{Ca}, \mathrm{Th})$ phosphates in monazite and xenotime solid solutions reflects the ratio of these elements in aqueous solutions, which was

620 developed before interaction with the apatitebearing rock.

Once the apatite is exhausted from the rock, continuous flushing of the deposited xenotime and monazite with REE-, U-, and Th-bearing fluid

625 results in re-distribution of REE phosphates along the column. More mobile LREE, especially La and $\mathrm{Ce}$, are re-mobilized in accordance to reaction (6). At elevated temperature, La chloride complexes demonstrate the highest stability among the REE 630 chloride species (Figure 3). Thus, monazite-(La) quickly disappears from the beginning of the column, as it is mobilized by the solution closer to

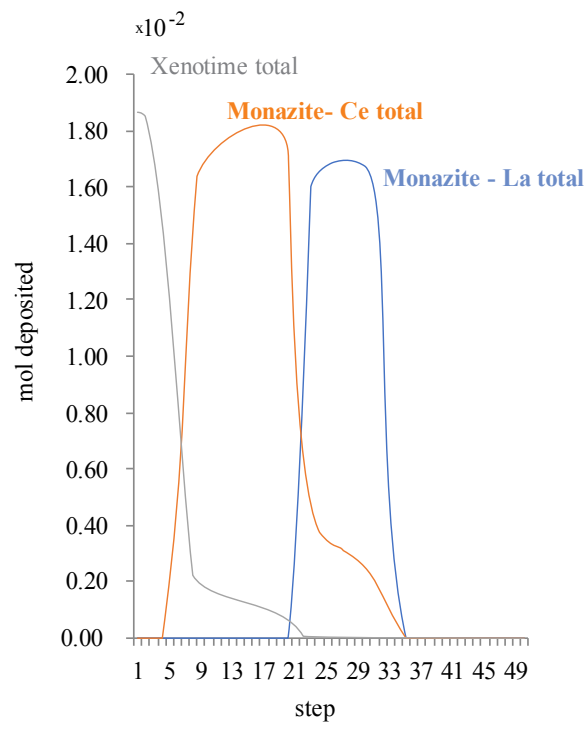

Figure 14. Distribution of total amounts of monazites and xenotime (mol) redeposited in the column at $250{ }^{\circ} \mathrm{C}$ after 10 waves (flushes) in a system buffered with Hematite/Magnetite redox buffer. the alteration front, forming a deposition peak (). Re-distribution of monazite-(Ce) lags behind monazite-(La), and forms a deposition peak before the monazite-(La) peak. As shown in Figure 63514 , after only a few flushes of the fluid through the column, the separation of monazite-(La) and 

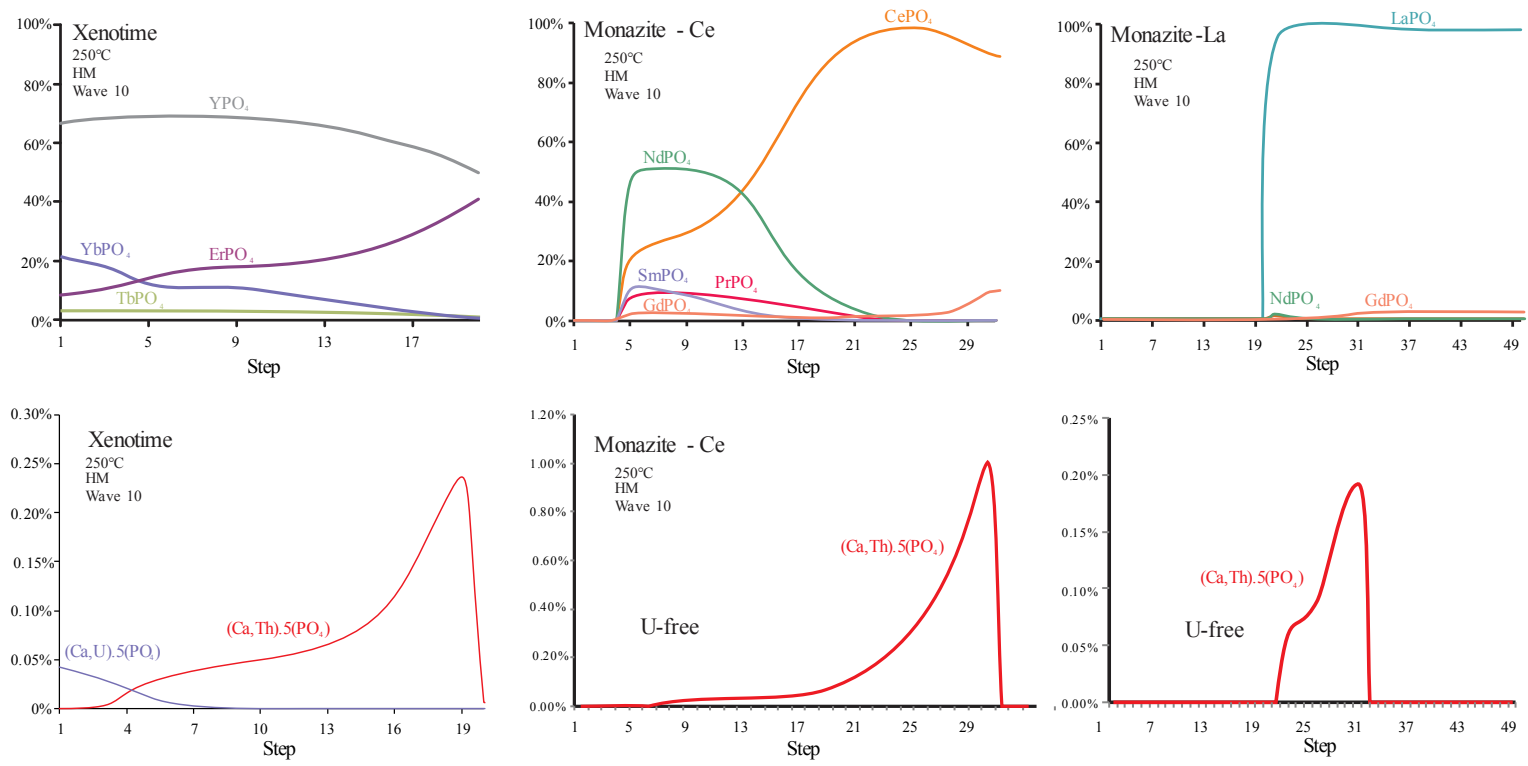

Figure 15. Concentrations of end-members in re-deposited REE phosphates $\left(250{ }^{\circ} \mathrm{C}, \mathrm{HM}, 10\right.$ waves)

monazite-(Ce) is nearly complete. Interestingly, whereas the content of the re-distributed monazite-(La) is $99 \mathrm{~mol}_{\%} \mathrm{LaPO}_{4}$, and this phase is highly depleted of other REE phosphate endmembers, the composition of the re-distributed monazite- $(\mathrm{Ce})$ varies significantly (Figure 15). Closer to the alteration front, the re-distributed monazite-(Ce) contains more than $99 \mathrm{~mol} \%$ $640 \mathrm{CePO}_{4}$, with only trace amounts of other phosphate end-members, mostly $\mathrm{NdPO}_{4}$. However, at the tail of the monazite-(Ce) re-distribution peak, the content of $\mathrm{NdPO}_{4}$ increases by up to 50 mol\%, accompanied with an appreciable increase of other phosphate end-members $(\sim 10 \mathrm{~mol} \%$ $\mathrm{SmPO}_{4}$ and $\left.\mathrm{PrPO}_{4}\right)$. The composition of monazite-(Ce) in this area of the column permits us to classify this phase as monazite-(Nd), the most industry-sought type of monazite. Monazite-(Ce)

645 also co-deposits with monazite-(La) at $20 \mathrm{~mol} \%$ level (Figure 14). In this range, monazite-(Ce) becomes enriched with the $\mathrm{GdPO}_{4}$ end-member; we do not exclude however that this can be an artifact of our simplistic description of solid solution and artificial separation of monazite to two phases due to restrictions of the applied software. A more complex model will likely include monazite-(Ce) co-deposited with monazite-(La) into the composition of the latter. At high 650 temperatures, stability of HREE chloride complexes is lowest in the REE group of elements, and, thus, re-distribution of xenotime along the column is the least significant among the solid solutions considered in our model. The deposition of xenotime occurs at the beginning of the column, and while the solution flushes through the system, re-distributes it to the areas preceding that of re-distribution peak of monazite-(Ce). Compositions of re-distributed xenotime also 655 follow the trend observed for monazites: depletion of lighter end member REE phosphates $\left(\mathrm{ErPO}_{4}\right.$, in the case of xenotime) at the beginning of the re-distribution peak, and its enrichment closer to the end of this peak. The model also suggests co-deposition of xenotime with monazite(Ce) at $\sim 5 \mathrm{~mol} \%$ level. This, however, also could be an artifact of over-simplified solid solution models used in our calculations: a more complex model can potentially include the $5 \mathrm{~mol} \%$ components of co-deposited xenotime into the composition of monazite. 
Thus, our model shows that after 5 to 10 flushes of the solution through the system, complete separation of the REE phosphates: xenotime, monazite-(Nd), monazite-(Ce), and monazite-( $\mathrm{La})$ was evident. The trends described above were observed for all temperatures evaluated in our model, and, considering our model only accounted for REE(III), REE was redox insensitive for 665 all oxygen fugacities.

With excess REE in aqueous solution, Th deposits within both xenotime and monazite solid solutions. Its distribution along the column behaves similarly to that of REE: mobilization of Th from the beginning of the 670 column and re-deposition closer to the alteration front. Combined with the separation of REE phosphates described above, re-distributed Th primarily occurs in monazite, while xenotime becomes depleted. The amount of $(\mathrm{Ca}, \mathrm{Th}) \mathrm{PO}_{4}$ deposited along the column are 675 shown on Figure 16; as seen in the figure the main mass of re-distributed $\mathrm{Th}$ is associated with the deposition of monazite. Our model therefore suggests that under the tested conditions, Th preferentially fractionates into monazite, which is consistent with the 680 crystal-chemical argument described earlier.

In contrast to Th, $U$ strictly and preferentially fractionates into to xenotime. With the exception of the initial depositional event (first encounter of unaltered solution with unaltered rock), at which $\mathrm{U}$ 685 incorporates in both monazite and xenotime, $\mathrm{U}$ was not found in any re-distributed monazites, and all occurrence of $(\mathrm{Ca}, \mathrm{U}) \mathrm{PO}_{4}$ end-member was associated with xenotime. Interestingly, although we tested significantly different redox conditions in our model, 690 which should result in substantial differences in the mobility of $\mathrm{U}$, the abovementioned trend remained the same. Thus, the model suggests very high stability of $(\mathrm{Ca}, \mathrm{U}) \mathrm{PO}_{4}$ end-member in xenotime solid solution, whereby irrespective of total concentrations of $U$ in

695 solution and the oxidation state of this element, formation of xenotime effectively immobilizes all $\mathrm{U}$ available in solution, preventing its incorporation into the monazites. The amount of $(\mathrm{Ca}, \mathrm{U}) \mathrm{PO}_{4}$ deposited along the column are shown in ; as it can be seen from the figure the main mass of re-distributed $U$ is strictly associated with deposition of xenotime.

\section{Discussion}

The calculations reported in this contribution confirm the conclusions obtained in our earlier, more simplistic models [3,87]: deposition/re-distribution of REE phosphates from/by hydrothermal acidic NaCl-rich natural fluids can potentially lead to a very efficient separation of 
705 xenotime from monazite. The main driving force of this separation is the increase in stability of chloride complexes of LREE, comparing to that of HREE, which occurs at elevated temperatures (Figure 3). Chloride complexes of the REE remain weak at elevated $\mathrm{T}$, however this is overwhelmed by high concentrations of chloride in solutions responsible in nature for the transport and concentration of REE to economic levels. Deposition of xenotime and monazite 710 from aqueous solution requires a source of phosphate. In our calculations, which reflect the most likely scenario in nature, the source of phosphate is apatite or whitlockite $\left(\mathrm{Ca}_{5}\left(\mathrm{PO}_{4}\right)_{3} \mathrm{OH}\right.$ and $\left.\mathrm{Ca}_{3}(\mathrm{PO} 4)_{2}\right)$ that are present in trace concentrations in the rock. The presence of these minerals in a rock through which REE-bearing aqueous solution flowed would form a geochemical barrier and initiate deposition of REE phosphates, e.g.:

$\mathrm{Ca}_{5}\left(\mathrm{PO}_{4}\right)_{3} \mathrm{OH}+3 \mathrm{REECl}^{2+}+\mathrm{H}^{+}=3 \mathrm{REEPO}_{4}+3 \mathrm{CaCl}^{+}+2 \mathrm{Ca}^{2+}+\mathrm{H}_{2} \mathrm{O}$

As it can be seen from equation (7), interaction of dissolved REE with apatite is an $\mathrm{H}^{+}$ consuming reaction. Strictly speaking, this reaction is not a $\mathrm{pH}$-buffering process, however, at given concentrations of apatite in the rock, its complete consumption through the formation of REE phosphates can be considered as an analogue of a $\mathrm{pH}$-buffering process. The solubility of 720 REE phosphates is significantly lower than that of apatite (and most naturally occurring phosphates, Figure 17); thus, until apatite is present in the rock, the formation of REE phosphates occurs indiscriminately by removing effectively all REE load from the solution.

725 The observed separation of monazite and xenotime begins when all apatite content is exhausted (reaction 6). Flushing hydrothermal fluid through the

730 column depletes the already deposited REE phosphates with LREE, and re-mobilizes them to a new location, leaving HREEenriched phases behind. This

735 suggests that the effects of this separation should be visible in well-

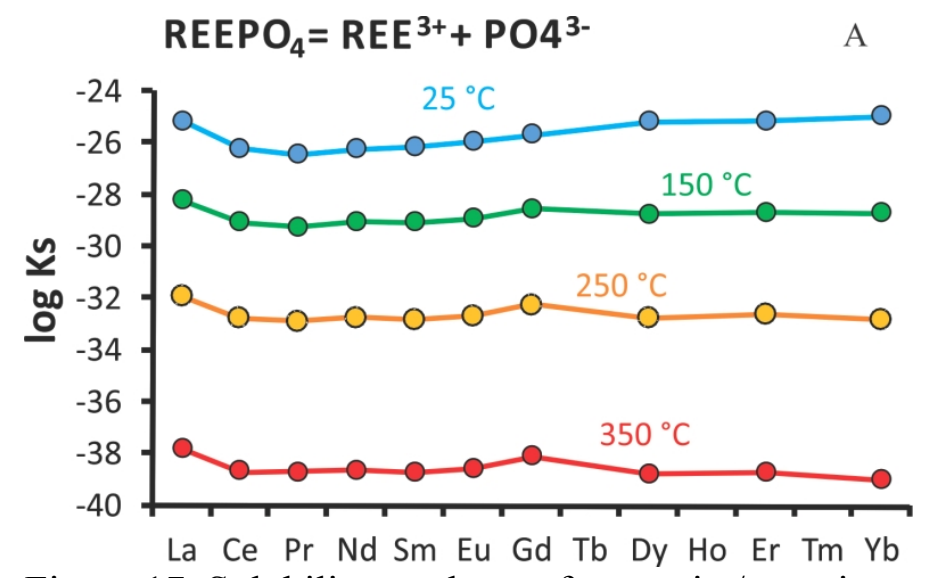

Figure 17. Solubility products of monazite/xenotime end members as a function of temperature evolved hydrothermal systems, characterized by relatively high fluid/rock ratio, when REEcarrying capacity of a fluid exceeds binding capacity of a rock. In this case, xenotime should be found in the most evolved parts of the system, characterized by highest fluid/rock ratio, whereas 740 monazite can be found at the periphery of the system with lower fluid/rock ratios. Another scenario that can lead to a similar effect is the late alteration of already deposited REE phosphates by REE-free hydrothermal fluids. Although this scenario has not been evaluated in our model, it is evident that the processes occurring in such systems should be similar to that modeled in this contribution.

745 A critical reservation when discussing the results of our model is the behavior of $\mathrm{Y}$ in hydrothermal aqueous solutions. It should be recalled that due to a lack of any experimental or theoretical evaluation of the properties of $\mathrm{Y}$ chloride species at elevated temperatures, in the calculations reported above these properties were assumed to be identical to those of Ho chloride species. This assumption is highly approximate; accurate description of its behavior in NaCl- 
750 bearing solutions requires accumulation of experimental information. At the same time, $\mathrm{Y}$ is the main mineral-forming element in xenotime, and therefore potential inaccuracy in the description of its behavior in aqueous solution can cause deviations of the dependencies observed in our model from the true trends.

A notable finding returned by our model is the behavior of $U$ and Th during the processes of 755 hydrothermal deposition and fractionation of REE. Our model suggests Th preferentially fractionates into monazite, while $U$ is strongly bound to xenotime. Indeed, this fractionation has been documented for natural monazites and xenotimes. For example, strong fractionation of Th and $U$ into monazite and xenotime, respectively has been recorded in REE phosphates found in metapelites and granites in Germany [88,89]; extreme enrichment of Th versus U was found in 760 hydrothermally altered monazites in Swiss Alps [90]; and finally, a very similar effect of fractionation of $U$ and $T h$ has been documented for minerals growing during hydrothermal alteration at contact boundaries between granite and gabbro in the Unazuki region, Japan [90]. The above findings suggest that, although highly simplified, the model proposed in this contribution reproduces general trends observed in natural systems.

765 The opposing behavior of $U$ and $\mathrm{Th}$ can be attributed to the differences in the REE polyhedral sites between the monazite and xenotime structure (Fig. 1). In the parent $\mathrm{CePO}_{4} \mathrm{monazite}$ structure, the ionic radius of $\mathrm{Ce}^{3+}$ in a nine-coordinated site is $1.196 \AA$. By contrast, in the parent $\mathrm{YPO}_{4}$ xenotime structure, the ionic radius of $\mathrm{Y}^{4+}$ in an eight-coordinated site is $1.019 \AA$ [9]. Thus, it is not surprising that the larger M/LREE favors the monazite structure the smaller HREE

770 prefers the xenotime structure. Since $\mathrm{Th}$ is larger than $\mathrm{U}$ (the ionic radii of $\mathrm{Th}^{4+}$ and $\mathrm{U}^{4+}$ in an eightfold coordination are $1.09 \AA$ and $1.05 \AA$ ), Th favors the more expanded monazite structure and $U$ favors the denser xenotime structure. This situation is even truer with the concomitant incorporation of the larger $\mathrm{Ca}^{2+}$ (the ionic radii of $\mathrm{Ca}^{2+}$ in an eightfold and ninefold coordination are $1.12 \AA$ and $1.18 \AA$, respectively) into either structure to achieve charge neutrality, especially 775 when the concentration of $\mathrm{Ca}+\mathrm{U}$ or $\mathrm{Ca}+\mathrm{Th}$ is relatively low.

The model reported in this contribution, unfortunately, does not propose any mechanisms for formation of $U$ - or Th-free monazites or xenotimes. Presence of actinides in aqueous solutions inevitably leads to the formation of either U-containing xenotimes, or Th-containing monazites, irrespective of the degree of alteration. We note, however, that in systems of different chemistry

780 (e.g., systems with sulfate- or carbonate-ligands), U or Th complexes potentially might be more stable (and, thus, more mobile) than those accounted for in our calculations, and there is still potential possibility that the Th-free monazites can be formed due to higher mobilization capacity of the fluids.

\section{Conclusions}

785 The model reported in this contribution confirms our preliminary conclusions [3,87] and demonstrates that the interaction of REE phosphates with $\mathrm{NaCl}$-rich acidic fluid can lead to the complete separation of xenotimes that are rich in M/LREE from monazites that are rich in HREE. This separation is accompanied by preferential fractionation of $U$ to xenotime and Th to monazite. Both monazite/xenotime separation and $\mathrm{U} / \mathrm{Th}$ fractionation are consistent with the

790 crystal-chemical argument on the differences between the two parent structures in the context of substituting ionic size effect. This phenomenon is known from natural observations and has been documented for a number of naturally occurring monazites and xenotimes. 


\section{Acknowledgments}

795 Research presented in this article was supported by the Laboratory Directed Research and Development program of Los Alamos National Laboratory under project number 20180007DR and by the CSES Emerging Ideas R\&D grant (LANL) to A.M.

\section{References}

[1] R. U.S. Department of Energy, U.S. Department of Energy. Critical Materials Strategy, Washington, D.C., 2011.

[2] R. U.S. Geological Survey, U.S. Geological Survey: Mineral Commodity Summaries 2017, Reston, Virginia, 2017. https://minerals.usgs.gov/minerals/pubs/mcs/2017/mcs2017.pdf.

[3] A. Migdisov, A.E. Williams-Jones, J. Brugger, F.A. Caporuscio, Hydrothermal transport, deposition, and fractionation of the REE: Experimental data and thermodynamic calculations, Chem. Geol. 439 (2016) 13-42. doi:10.1016/j.chemgeo.2016.06.005.

810 [4] D. Banks, B. Yardley, A. Campbell, K. Jarvis, REE composition of an aqueous magmatic fluid: A fluid inclusion study from the Capitan Pluton, New Mexico, U.S.A., Chem. Geol. 113 (1994) 259-272. doi:10.1016/0009-2541(94)90070-1.

[5] R. Gratz, W. Heinrich, Monazite-xenotime thermobarometry: Experimental calibration of the miscibility gap in the binary system CePO4-YPO4., Am. Mineral. 82 (1997) 772-780.

815 [6] Y. Ni, J.M. Hughes, A.N. Mariano, Crystal chemistry of the monazite and xenotime structures, Am. Mineral. 80 (1995) 21-26.

[7] M. Cuney, M. Friedrich, Physicochemical and crystal-chemical controls on accessory mineral paragenesis in granitoids: implications for uranium metallogenesis, B Miner. 110 (1987) 235-247.

820 [8] E.R. Vance, Y. Zhang, T. McLeod, J. Davis, Actinide valences in xenotime and monazite, J. Nucl. Mater. 409 (2011) 221-224.

[9] R.D. Shannon, Revised effective ionic radii and systematic studies of interatomic distances in halides and chalcogenides, Acta Crystallogr. A32 (1976) 751-767.

[10] T. Ault, B. Van Gosen, S. Krahn, A. Croff, Natural Thorium Resources and Recovery: Options and Impacts, Nucl. Technol. 194 (2016) 136-151.

[11] C. Sonich-Mullin, Rare Earth Elements : A Review of Production, Processing, Recycling , and Associated Environmental Issues Rare Earth Elements : A Review of Production, Processing, Recycling, and Associated Environmental Issues, Washington, D.C., 2012.

[12] M. Findeiß, A. Schaffer, Fate and Environmental Impact of Thorium Residues During Rare Earth Processing, J.Sustain. Met. (2016). doi:10.1007/s40831-016-0083-3.

[13] Y. Shvarov, E. Bastrakov, HCh: A Software Package for Geochemical Equilibrium Modeling - User's Guide., Aust. Geol. Surv. Organ. Rec. 1999. 25 (1999) 61.

[14] M. Smith, P. Henderson, Preliminary fluid inclusion constraints on fluid evolution in the Bayan Obo Fe-REE-Nb deposit, Inner Mongolia, China, Econ. Geol. 95 (2000) 1371. doi:10.2113/95.7.1371.

[15] A.E. Williams-Jones, I.M. Samson, G.R. Olivo, The genesis of hydrothermal fluorite-REE deposits in the Gallinas Mountains, New Mexico, Econ. Geol. 95 (2000) 327-341.

[16] B. Lehmann, S. Nakai, A. Höhndorf, J. Brinckmann, P. Dulski, U. Hein, A. Masuda, REE 
mineralization at Gakara, Burundi: Evidence for anomalous upper mantle in the western Rift Valley, Geochim. Cosmochim. Acta. 58 (1994) 985-992.

[17] A.P. Gysi, A.E. Williams-Jones, Hydrothermal mobilization of pegmatite-hosted REE and $\mathrm{Zr}$ at Strange Lake, Canada: A reaction path model, Geochim. Cosmochim. Acta. 122 (2013) 324-352. doi:10.1016/j.gca.2013.08.031.

[18] J. Kestin, J. Sengers, B. Kamgar-Parsi, Thermophysical Properties of Fluid H20, J. Phys. Chem. Ref. 13 (1984) 175-183. http://potomac.nist.gov/srd/PDFfiles/jpcrd250.pdf (accessed July 14, 2010).

[19] W.L. Marshall, E.U. Franck, Ion Product of Water Substance, 0-1000 ${ }^{\circ}$, 1-10,000 Bars. New International Formulation and Its Background, J. Phys. Chem. Ref. Data. 10 (1981) 295-304.

850 [20] E. Oelkers, H.C. Helgeson, Calculation of activity coefficients and degrees of formation of neutral ion pairs in supercritical electrolyte solutions, Geochim. Cosmochim. Acta. 55 (1991) 1235-1251. doi:10.1016/0016-7037(91)90303-M.

[21] E. Oelkers, H.C. Helgeson, Triple-ion anions and polynuclear complexing in supercritical electrolyte solutions, Geochim. Cosmochim. Acta. 54 (1990) 727-738. doi:10.1016/00167037(90)90368-U.

[22] J.W. Johnson, E.H. Oelkers, H.C. Helgeson, SUPCRT92: A software package for calculating the standard molal thermodynamic properties of minerals, gases, aqueous species, and reactions from 1 to 5000 bar and 0 to $1000^{\circ} \mathrm{C}$, Comput. Geosci. 18 (1992) 899-947. doi:10.1016/0098-3004(92)90029-Q.

860 [23] E.L. Shock, D.C. Sassani, M. Willis, D.A. Sverjensky, Inorganic species in geologic fluids: correlations among standard molal thermodynamic properties of aqueous ions and hydroxide complexes., Geochim. Cosmochim. Acta. 61 (1997) 907-50. http://www.ncbi.nlm.nih.gov/pubmed/11541225.

[24] D. Sverjensky, E.L. Shock, H.C. Helgeson, Prediction of the thermodynamic properties of aqueous metal complexes to $1000 \mathrm{C}$ and $5 \mathrm{~kb}$, Geochim. Cosmochim. Acta. 61 (1997) 1359-1412. doi:10.1016/S0016-7037(97)00009-4.

[25] B.R. Tagirov, A. Zotov, N. Akinfiev, Experimental study of dissociation of $\mathrm{HCl}$ from 350 to $500^{\circ} \mathrm{C}$ and from 500 to 2500 bars: Thermodynamic properties of $\mathrm{HCl}^{\circ}(\mathrm{aq})$, Geochim. Cosmochim. Acta. 61 (1997) 4267-4280. doi:10.1016/S0016-7037(97)00274-3.

870 [26] P.C. Ho, D.A. Palmer, M.S. Gruszkiewicz, Conductivity Measurements of Dilute Aqueous $\mathrm{HCl}$ Solutions to High Temperatures and Pressures Using a Flow-Through Cell, J. Phys. Chem. B. 105 (2001) 1260-1266.

[27] T. Holland, R. Powell, An internally consistent thermodynamic data set for phases of petrological interest, J. Metamorph. Geol. 16 (1998) 309-343.

875 http://www3.interscience.wiley.com/journal/119118597/abstract (accessed January 29, 2011).

[28] E.L. Shock, D.C. Sassani, H. Betz, Uranium in geologic fluids: Estimates of standard partial molal properties, oxidation potentials, and hydrolysis constants at high temperatures and pressures, Geochim. Cosmochim. Acta. 61 (1997) 4245-4266. doi:10.1016/S0016-7037(97)00240-8.

[29] J. Haas, E.L. Shock, D. Sassani, Rare earth elements in hydrothermal systems: estimates of standard partial molal thermodynamic properties of aqueous complexes of the rare earth elements at high, Geochim. Cosmochim. Acta. 59 (1995) 4329-4350. doi:10.1016/00167037(95)00314-P. 
[30] S. Wood, D. Palmer, D. Wesolowski, P. Bénézeth, The aqueous geochemistry of the rare earth elements and yttrium. Part XI. The solubility of $\mathrm{Nd}(\mathrm{OH}) 3$ and hydrolysis of $\mathrm{Nd} 3+$ from 30 to $290 \mathrm{C}$ at saturated water vapor pressure with in-situ $\mathrm{pHm}$ measurement, in: R. Hellmann, S.A. Wood (Eds.), Water-Rock Interact. Ore Depos. Environ. Geochemistry A Tribut. to David A. Crerar, 2002: pp. 229-256. doi:10.1016/0009-2541(90)90080-Q.

890 [31] Y. Luo, R.H. Byrne, Yttrium and rare earth element complexation by chloride ions at 25 C, J. Solution Chem. 30 (2001) 837-845. http://www.springerlink.com/index/Q332187111792NJM.pdf (accessed November 18, 2011).

[32] M. Altmaier, E. Yalçıntaş, X. Gaona, V. Neck, R. Müller, M. Schlieker, T. Fanghänel, Solubility of U(VI) in chloride solutions. I. The stable oxides/hydroxides in $\mathrm{NaCl}$ systems, solubility products, hydrolysis constants and SIT coefficients, J. Chem. Thermodyn. 114 (2017) 2-13. doi:10.1016/j.jct.2017.05.039.

[33] P. Wang, A. Anderko, J.J. Kosinski, R.D. Springer, M.M. Lencka, Modeling Speciation and Solubility in Aqueous Systems Containing U(IV, VI), Np(IV, V, VI), Pu(III, IV, V,

[34] Y. Xing, Y. Mei, B. Etschmann, W. Liu, J. Brugger, Uranium transport in F-Cl-bearing fluids and hydrothermal upgrading of U-Cu ores in IOCG deposits, Geofluids. (2018) in press.

[35] G.A. Parks, D.C. Pohl, Hydrothermal solubility of uraninite, Geochim. Cosmochim. Acta. 52 (1988) 863-875.

[36] A. Timofeev, A.A. Migdisov, A.E. Williams-Jones, R. Roback, A.T. Nelson, H. Xu, Uranium transport in acidic brines under reducing conditions, Nat. Commun. 9 (2018) 17. doi:10.1038/s41467-018-03564-7.

[37] I. Grenthe, J. Fuger, R.J.M. Konings, R.J. Lemire, A.B. Muller, C. Nguyen-Trung, CHEMICAL THERMODYNAMICS OF URANIUM, OECD Nuclear Energy Agency, Data Bank, Issy-les-Moulineaux (France), 1992.

[38] R. Guillaumont, T. Fanghänel, J. Fuger, I. Grenthe, V. Neck, D.A. Palmer, M.H. Rand, Update on the chemical thermodynamics of uranium, neptunium, plutonium, americium and technetium., 2003.

915 [39] B.N. Ryzhenko, O. V. Bryzgalin, I.Y. Artamkina, M.Y. Spasennykh, A.I. Shapkin, An electrostatic model for the electrolytic dissociation of inorganic substances dissolved in water., Geochem. Int. 22 (1985) 138-144.

[40] H. Nisbet, A. Migdisov, H. Xu, X. Guo, V. van Hinsberg, A.E. Williams-Jones, H. Boukhalfa, R. Roback, An experimental study of the solubility and speciation of thorium in chloride-bearing aqueous solutions at temperatures up to $250{ }^{\circ} \mathrm{C}$., Geochim. Cosmochim. Acta, Press. (n.d.).

[41] A.A. Migdisov, H. Boukhalfa, A. Timofeev, W. Runde, R. Roback, A.E. Williams-Jones, A spectroscopic study of uranyl speciation in chloride-bearing solutions at temperatures up to $250^{\circ} \mathrm{C}$, Geochim. Cosmochim. Acta. 222 (2018) 130-145.

925 doi:10.1016/j.gca.2017.10.016.

[42] M. Dargent, J. Dubessy, L. Truche, E.F. Bazarkina, C. Nguyen-Trung, P. Robert, Experimental study of uranyl(VI) chloride complex formation in acidic $\mathrm{LiCl}$ aqueous solutions under hydrothermal conditions $\left(\mathrm{T}=21 \mathrm{C}-350^{\circ} \mathrm{C}\right.$, Psat) using Raman spectroscopy, Eur. J. Mineral. 25 (2013) 765-775. doi:10.1127/0935-1221/2013/00252319. 
[43] A.A. Migdisov, W. Runde, A.E. Williams-Jones, H. Boukhalfa, R. Roback, A. Timofeev, Response to the comment "Uranyl-chloride speciation and uranium transport in hydrothermal brines: Comment on Migdisov et al. (2018)" by Dargent et al., Geochim. Cosmochim. Acta. 235 (2018) 509-512. doi:10.1016/j.gca.2018.06.015.

935 [44] M.H. Rand, F.J. Mompean, J. Perrone, M. Illemassene, Chemical Thermodynamics of Thorium, OECD, NEA, 2008.

[45] P.L. Zanonato, P.D. Bernardo, Z. Zhang, Y. Gong, G. Tian, J.K. Gibson, L. Rao, Hydrolysis of thorium(IV) at variable temperatures, Dalt. Trans. 45 (2016) 12763-12771.

[46] V. Neck, J.I. Kim, Solubility and hydrolysis of tetravalent actinides, Radiochim. Acta. 91

940 (2003) 253-262.

[47] D. Rai, A.R. Felmy, S.M. Sterner, D.A. Moore, M.J. Mason, The Solubility of Th(IV) and U(IV) Hydrous Oxides in Concentrated $\mathrm{NaCl}$ and $\mathrm{MgCl}$ Solutions, Radiochim. Acta. 79 (1997) 239-247.

[48] I. Grenthe, B. Lagerman, Studies on metal carbonate equilibria: 23. Complex formation in the Th(IV)-H2O-CO2(g) system, Acta Chem. Scand. 45 (1991) 231-238.

[49] R.A. Robie, B.S. Hemingway, Thermodynamic properties of minerals and related substances at $298.15 \mathrm{~K}$ and 1 Bar (105 Pascals) pressure and at higher temperatures., U. S. Geol. Surv. Bull. 2131 (1995) 461.

[50] K. Popa, D. Sedmidubsky, O. Benes, C. Thiriet, R. Konings, The high-temperature heat capacity of LnPO4 (Ln=La, Ce, Gd) by drop calorimetry, J. Chem. Thermodyn. 38 (2006) 825-829. doi:10.1016/j.jct.2005.08.019.

[51] K. Popa, R.J.M. Konings, High-temperature heat capacities of EuPO4 and SmPO4 synthetic monazites, Thermochim. Acta. 445 (2006) 49-52. doi:10.1016/j.tca.2006.03.023.

955 [52] A. Navrotsky, W. Lee, A. Mielewczyk-Gryn, S. V. Ushakov, A. Anderko, H. Wu, R.C. Riman, Thermodynamics of Solid Phases Containing Rare Earth Oxides, J. Chem. Thermodyn. 88 (2015) 126-141. doi:10.1016/j.jct.2015.04.008.

[53] X. Liu, R.H. Byrne, Rare earth and yttrium phosphate solubilities in aqueous solution, Geochim. Cosmochim. Acta. 61 (1997) 1625-1633. doi:10.1016/S0016-7037(97)00037-9.

960 [54] F. Poitrasson, E. Oelkers, J. Schott, J.-M. Montel, Experimental determination of synthetic $\mathrm{NdPO} 4$ monazite end-member solubility in water from $21^{\circ} \mathrm{C}$ to $300^{\circ} \mathrm{C}$ : implications for rare earth element mobility in crustal fluids, Geochim. Cosmochim. Acta. 68 (2004) 2207-2221. doi:10.1016/j.gca.2003.12.010.

[55] E. Pourtier, J.-L. Devidal, F. Gibert, Solubility measurements of synthetic neodymium monazite as a function of temperature at $2 \mathrm{kbars}$, and aqueous neodymium speciation in equilibrium with monazite, Geochim. Cosmochim. Acta. 74 (2010) 1872-1891. doi:10.1016/j.gca.2009.12.023.

[56] K.S. Gavrichev, M. a. Ryumin, a. V. Tyurin, V.M. Gurevich, L.N. Komissarova, Heat capacity and thermodynamic functions of xenotime YPO4(c) at 0-1600 K, Geochemistry Int. 48 (2010) 932-939. doi:10.1134/S0016702910090065.

[57] K.S. Gavrichev, M. a. Ryumin, a. V. Tyurin, V.M. Gurevich, a. V. Khoroshilov, L.N. Komissarova, Thermodynamic functions of erbium orthophosphate ErPO4 in the temperature range of $0-1600 \mathrm{~K}$, Thermochim. Acta. 535 (2012) 1-7. doi:10.1016/j.tca.2012.02.002.

975 [58] K.S. Gavrichev, N.N. Smirnova, V.M. Gurevich, V.P. Danilov, a. V. Tyurin, M. a. Ryumin, L.N. Komissarova, Heat capacity and thermodynamic functions of LuPO4 in the 
range 0-320K, Thermochim. Acta. 448 (2006) 63-65. doi:10.1016/j.tca.2006.05.019.

[59] K.S. Gavrichev, M. a. Ryumin, a. V. Tyurin, V.M. Gurevich, G.E. Nikiforova, L.N. Komissarova, Heat capacity and thermodynamic functions of YbPO4 from 0 to $1800 \mathrm{~K}$, Inorg. Mater. 49 (2013) 701-708. doi:10.1134/S0020168513070042.

[60] K.S. Gavrichev, M.A. Ryumin, A.V. Khoroshilov, G.E. Nikiforova, A.V. Tyurin, V.M. Gurevich, R.V. Starykh, Thermodynamic properties and phase transitions of tetragonal modification of terbium orthophosphate, Vestn. St.Petersbg. State Univ. 4 (2013) 186197.

985 [61] A.P. Gysi, A.E. Williams-Jones, D. Harlov, The solubility of xenotime-(Y) and other HREE phosphates (DyPO4, ErPO4 and YbPO4) in aqueous solutions from 100 to $250^{\circ} \mathrm{C}$ and psat, Chem. Geol. 401 (2015) 83-95. doi:10.1016/j.chemgeo.2015.02.023.

[62] J. Finney, N.N. Rao, The crystal structure of cheralite, Am. Mineral. J. Earth Planet. Mater. 52 (1967) 13-19.

990 [63] H.-J. Forster, The chemical composition of REE-Y-Th-U-rich accessory minerals in peraluminous granites of the Erzgebirge-Fichtelgebirge region, Germany, Part I: The monazite-(Ce)-brabantite solid solution series, Am. Mineral. 83 (1998) 259-272.

[64] J. Hughes, E. Foord, M. Hubbard, Y. Ni, The Crystal-Structure Of Cheralite-(Ce),(LREE, $\mathrm{Ca}, \mathrm{Th}, \mathrm{U})(\mathrm{P}, \mathrm{Si}) \mathrm{O}-4$, A Monazite-Group Mineral, Neues Jahrb. Fur Mineral. 8 (1995) 344-350.

[65] A.-M. Seydoux-Guillaume, R. Wirth, W. Heinrich, J.-M. Montel, Experimental determination of thorium partitioning between monazite and xenotime using analytical electron microscopy and X-ray diffraction Rietveld analysis., Eur. J. Mineral. 14 (2002) 869-878.

1000 [66] H.J. Forster, Composition and origin of intermediate solid solutions in the system thoritexenotime-zircon-coffinite, Lithos. 88 (2006) 35-55.

[67] K. Popa, T. Shvareva, L. Mazeina, E. Colineau, F. Wastin, R.J.M. Konings, a. Navrotsky, Thermodynamic properties of CaTh(PO4)2 synthetic cheralite, Am. Mineral. 93 (2008) 1356-1362. doi:10.2138/am.2008.2794.

1005 [68] D. Rawat, S. Phapale, R. Mishra, S. Dash, Thermodynamic studies on charge-coupled substituted synthetic monazite, J. Nucl. Mater. 847 (2017) 406-417.

[69] T. Muto, Thermochemical stability of ningyoite, Mineral. J. 4 (1965) 245-274.

[70] X.F. Guo, S. Szenknect, A. Mesbah, N. Clavier, C. Poinssot, D. Wu, H.W. Xu, N. Dacheux, R.C. Ewing, A. Navrotsky, Energetics of a Uranothorite (Th1-xUxSiO4) Solid Solution, Chem Mater. 28 (2016) 7117-7124.

[71] H. Xu, A. Navrotsky, M.L. Balmer, Y. Su, Perovskite solid solutions along the NaNbO3SrTiO3 join: Phase transitions, formation enthalpies, and implications for general perovskite energetics., Chem. Mater. 17 (2005) 1880-1886.

[72] H. Xu, P.J. Heaney, G. Beall, Phase transitions induced by solid solution in stuffed derivatives of quartz: A powder synchrotron XRD study of the LiAlSiO4-SiO2 join, Am. Mineral. 85 (2000) 971-979.

[73] H. Xu, Y. Su, M. Balmer, A. Navrotsky, A New Series of Oxygen-Deficient Perovskites in the NaTixNb1-xO3-0.5x System: Synthesis, Crystal Chemistry, and Energetics, Chem. Mater. 15 (2003) 1872-1878.

1020 [74] H. Xu, A. Navrotsky, M.L. Balmer, Y. Su, E.R. Bitten, Energetics of substituted pollucites along the CsAlSi2O6-CsTiSi2O6.5 join: A high-temperature calorimetric study, J. Am. Ceram. Soc. 84 (2001) 555-560. 
[75] H. Xu, A. Navrotsky, M. Nyman, T. Nenoff, Octahedral microporous phases $\mathrm{Na} 2 \mathrm{Nb} 2-\mathrm{xTixO6}-\mathrm{x}(\mathrm{OH}) \mathrm{x} \cdot \mathrm{H} 2 \mathrm{O}$ and their related perovskites: Crystal chemistry, energetics, and stability relations, J. Mater. Res. 20 (2005) 618-627.

[76] K. Popa, R.J.M. Konings, T. Geisler, High-temperature calorimetry of (La1-xLnx)PO4 solid solutions, J. Chem. Thermodyn. 39 (2007) 236-239. doi:10.1016/j.jct.2006.07.010.

[77] R.J.M. Konings, M. Walter, K. Popa, Excess properties of the (Ln2-2xCaxThx)(PO4)2 (Ln=La, Ce) solid solutions, J. Chem. Thermodyn. 40 (2008) 1305-1308.

1030 doi:10.1016/j.jct.2008.03.009.

[78] Y. Li, P.M. Kowalski, A. Blanca-Romero, V. Vinograd, D. Bosbach, Ab initio calculation of excess properties of La1-x(Ln,An)(x)PO4 solid solutions, J Solid State Chem. 220 (2014) 137-141.

[79] J.D. Bauer, A. Hirsch, L. Bayarjargal, L. Peters, G. Roth, B. Winkler, Schottky contribution to the heat capacity of monazite type (La,Pr)PO4 from low temperature calorimetry and fluorescence measurements, Chem Phys Lett. 654 (2016) 97-102.

[80] A. Hirsch, P. Kegler, I. Alencar, J. Ruiz-Fuertes, A. Shelyug, L. Peters, C. Schreinemachers, A. Neumann, S. Neumeier, H.P. Liermann, A. Navrotsky, G. Roth, Structural, vibrational, and thermochemical properties of the monazite-type solid solution

[81] P.M. Kowalski, Y. Li, Relationship between the thermodynamic excess properties of mixing and the elastic moduli in the monazite-type ceramics, J Eur Ceram Soc. 36 (2016) 2093-2096.

[82] P. Mogilevsky, On the miscibility gap in monazite-xenotime systems, Phys Chem Min. 34 (2007) 201-214.

[83] J.G. Berryman, Bounds and self-consistent estimates for elastic constants of random polycrystals with hexagonal, trigonal, and tetragonal symmetries, J Mech Phys Solids. 53 (2005) 2141-2173.

[84] P. Mogilevsky, E.B. Zaretsky, T.A. Parthasarathy, F. Meisenkothen, Composition, lattice parameters, and room temperature elastic constants of natural single crystal xenotime from Novo Horizonte, Phys Chem Min. 33 (2006) 691-698.

[85] O. Gomis, B. Lavina, P. Rodriguez-Hernandez, A. Munoz, R. Errandonea, D. Errandonea, M. Bettinelli, High-pressure structural, elastic, and thermodynamic properties of zircontype HoPO4 and TmPO4, J Phys-Condens Mat. 29 (2017).

1055 [86] P. Glynn, Solid-solution solubilities and thermodynamics: sulfates, carbonates and halides, Rev. Mineral. Geochemistry. 40 (2000) 481-511.

[87] A.A. Migdisov, A.E. Williams-Jones, Hydrothermal transport and deposition of the Rare Earth Elements by fluorine-bearing aqueous liquids, Miner. Depos. 49 (2014) 987-997.

[88] G. Franz, G. Andrehs, D. Rhede, Crystal chemistry of monazite and xenotime from Saxothuringian-Moldanubian metapelites, NE Bavaria, Germany, Eur. J. Mineral. 8 (1996) 1097-1118. doi:10.1127/ejm/8/5/1097.

[89] H. Forster, The chemical composition of REE-Y-Th-U-rich minerals in peraluminous accessory granites of the Erzgebirge-Fichtelgebirge Part II : Xenotime region, Germany ., Am. Mineral. 83 (1998) 1302-1315. doi:10.2138/am-1998-3-409.

1065 [90] E. Janots, A. Berger, E. Gnos, M. Whitehouse, E. Lewin, T. Pettke, Constraints on fluid evolution during metamorphism from $\mathrm{U}-\mathrm{Th}-\mathrm{Pb}$ systematics in Alpine hydrothermal monazite, Chem. Geol. 326-327 (2012) 61-71. doi:https://doi.org/10.1016/j.chemgeo.2012.07.014. 
[91] C.H. Gammons, S.A. Wood, A.E. Williams-Jones, The aqueous geochemistry of the rare earth elements and yttrium: VI. Stability of neodymium chloride complexes from 25 to $300^{\circ} \mathrm{C}$, Geochim. Cosmochim. Acta. 60 (1996) 4615-4630. doi:10.1016/S00167037(96)00262-1.

[92] S. Stepanchikova, G. Kolonin, Spectrophotometric study of Nd, Sm, and Ho complexation in chloride solutions at 100-250 C, Russ. J. Coord. 31 (2005) 193-202.

1075 doi:10.1007/s11173-005-0076-4.

[93] A.A. Migdisov, A.E. Williams-Jones, A spectrophotometric study of neodymium (III) complexation in chloride solutions, Geochim. Cosmochim. Acta. 66 (2002) 4311-4323. doi:10.1016/S0016-7037(02)00995-X.

1080

[94] A.A. Migdisov, A.E. Williams-Jones, A spectrophotometric study of erbium (III) speciation in chloride solutions at elevated temperatures, Chem. Geol. 234 (2006) 17-27. doi:10.1016/j.chemgeo.2006.04.002.

[95] A.A. Migdisov, A.E. Williams-Jones, C. Normand, S.A. Wood, A spectrophotometric study of samarium (III) speciation in chloride solutions at elevated temperatures, Geochim. Cosmochim. Acta. 72 (2008) 1611-1625. doi:10.1016/j.gca.2008.01.007.

1085 [96] A.A. Migdisov, A.E. Williams-Jones, T. Wagner, An experimental study of the solubility and speciation of the Rare Earth Elements (III) in fluoride- and chloride-bearing aqueous solutions at temperatures up to $300^{\circ} \mathrm{C}$, Geochim. Cosmochim. Acta. 73 (2009) 70877109. doi:10.1016/j.gca.2009.08.023. 
Table 1. Concentrations of REE in the initial solution

1095 \begin{tabular}{llllllllllll} 
element & $\mathrm{Ce}$ & $\mathrm{La}$ & $\mathrm{Pr}$ & $\mathrm{Nd}$ & $\mathrm{Sm}$ & $\mathrm{Gd}$ & $\mathrm{Y}$ & $\mathrm{Tb}$ & $\mathrm{Dy}$ & $\mathrm{Er}$ & $\mathrm{Yb}$ \\
\hline $\begin{array}{l}\text { concentration } \\
(\mathrm{ppm})\end{array}$ & 300 & 300 & 35 & 150 & 20 & 20 & 100 & 6 & 45 & 33 & 33
\end{tabular}

Table 2. The thermodynamic properties of $\operatorname{LREE}(\mathrm{Ca}, \mathrm{Ac}) \mathrm{PO}_{4}[78,81]$

\begin{tabular}{|c|c|c|c|c|c|c|c|c|c|c|c|}
\hline Cation & $\mathrm{La}$ & $\mathrm{Ce}$ & $\operatorname{Pr}$ & $\mathrm{Nd}$ & $\mathrm{Pm}$ & $\mathrm{Sm}$ & $\mathrm{Eu}$ & $\mathrm{Gd}$ & $\mathrm{Ca}, \mathrm{Th}$ & $\mathrm{Ca}, \mathrm{U}$ & \\
\hline \multirow{10}{*}{$W_{x}(\mathrm{~kJ} / \mathrm{mol})$} & & 0.8 & 2.8 & 5.0 & 7.6 & 10.4 & 13.4 & 16.5 & 10.4 & 10.4 & $\mathrm{La}$ \\
\hline & & & 0.6 & 1.8 & 3.5 & 5.6 & 7.8 & 10.3 & 5.6 & 5.6 & $\mathrm{Ce}$ \\
\hline & & & & 0.4 & 1.3 & 2.6 & 4.2 & 6.1 & 2.6 & 2.6 & $\mathrm{Pr}$ \\
\hline & & & & & 0.3 & 1.0 & 2.1 & 3.6 & 1 & 1 & $\mathrm{Nd}$ \\
\hline & & & & & & 0.1 & 0.8 & 1.9 & 0.1 & 0.1 & $\mathrm{Pm}$ \\
\hline & & & & & & & 0.2 & 0.7 & 0 & 0 & $\mathrm{Sm}$ \\
\hline & & & & & & & & 0.2 & 0.2 & 0.2 & $\mathrm{Eu}$ \\
\hline & & & & & & & & & 0.7 & 0.7 & $G d$ \\
\hline & & & & & & & & & & 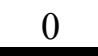 & $\mathrm{Ca}, \mathrm{Th}$ \\
\hline & & & & & & & & & & & $\mathrm{Ca}, \mathrm{U}$ \\
\hline
\end{tabular}

Table 3. The thermodynamic properties of $\operatorname{HREE}(\mathrm{Ca}, \mathrm{Ac}) \mathrm{PO}_{4}$.

\begin{tabular}{c|cccccccc|cc|c} 
Cation & Tb & Dy & $\mathbf{Y}$ & $\mathbf{H o}$ & $\mathbf{E r}$ & $\mathbf{T m}$ & $\mathbf{Y b}$ & $\mathbf{L u}$ & $\mathbf{C a}, \mathbf{T h}$ & $\mathbf{C a}, \mathbf{U}$ & \\
\hline$W_{x}(\mathrm{~kJ} / \mathrm{mol})$ & & 0.16 & 0.52 & 0.64 & 1.41 & 2.25 & 3.20 & 4.62 & 2.34 & 0.48 & $\mathbf{T b}$ \\
& & & 0.11 & 0.16 & 0.63 & 1.22 & 1.95 & 3.08 & 3.71 & 1.18 & $\mathbf{D y}$ \\
& & & & 0.01 & 0.22 & 0.61 & 1.14 & 2.04 & 5.07 & 1.99 & $\mathbf{Y}$ \\
& & & & & 0.15 & 0.49 & 0.98 & 1.83 & 5.43 & 2.22 & $\mathbf{H o}$ \\
& & & & & & 0.10 & 0.36 & 0.93 & 7.39 & 3.53 & $\mathbf{E r}$ \\
& & & & & & & 0.08 & 0.42 & 9.18 & 4.80 & $\mathbf{T m}$ \\
& & & & & & & & 0.13 & 11.03 & 6.16 & $\mathbf{Y b}$ \\
& & & & & & & & & 13.55 & 8.07 & $\mathbf{L u}$ \\
\hline$R_{x}(\AA)$ & 1.040 & 1.027 & 1.019 & 1.015 & 1.004 & 0.994 & 0.985 & 0.977 & $1.085^{\mathrm{a}}$ & $1.060^{\mathrm{a}}$ & \\
$\mathrm{V}_{\mathrm{x}}\left(\mathrm{cm}^{3} / \mathrm{mol}\right)$ & $43.83^{\mathrm{b}}$ & $43.35^{\mathrm{b}}$ & $42.95^{\mathrm{c}}$ & $42.85^{\mathrm{b}}$ & $42.37^{\mathrm{b}}$ & $41.99^{\mathrm{b}}$ & $41.63^{\mathrm{b}}$ & $41.19^{\mathrm{b}}$ & $45.71^{\mathrm{d}}$ & $44.68^{\mathrm{d}}$ & \\
$E_{x}(\mathrm{GPa})$ & $131.8^{\mathrm{e}}$ & $146.7^{\mathrm{e}}$ & $152.0^{\mathrm{f}}$ & $166.2^{\mathrm{g}}$ & $173.0^{\mathrm{e}}$ & $178.0^{\mathrm{g}}$ & $201.0^{\mathrm{h}}$ & $202.0^{\mathrm{i}}$ & & &
\end{tabular}

